\begin{tabular}{|c|c|c|c|c|c|c|}
\hline \multirow{4}{*}{ Impact Factor: } & ISRA (India) & $=3.117$ & SIS (USA) & $=0.912$ & ICV (Poland) & $=6.630$ \\
\hline & ISI (Dubai, UAE & $=0.829$ & РИНЦ (Russia & $=0.156$ & PIF (India) & $=1.940$ \\
\hline & GIF (Australia) & $=0.564$ & ESJI (KZ) & $=8.716$ & IBI (India) & $=4.260$ \\
\hline & JIF & $=1.500$ & SJIF (Morocco & $=5.667$ & OAJI (USA) & $=0.350$ \\
\hline
\end{tabular}

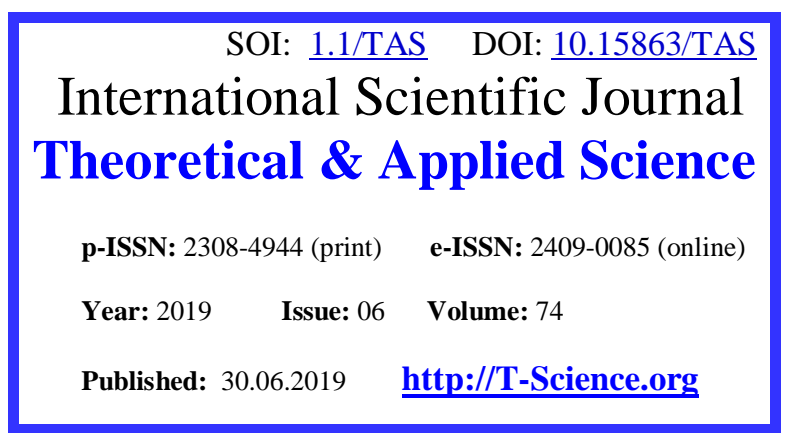

SECTION 31. Economic research, finance, innovation, risk management.

UDC 685:74 519.54.

\section{QR - Issue}
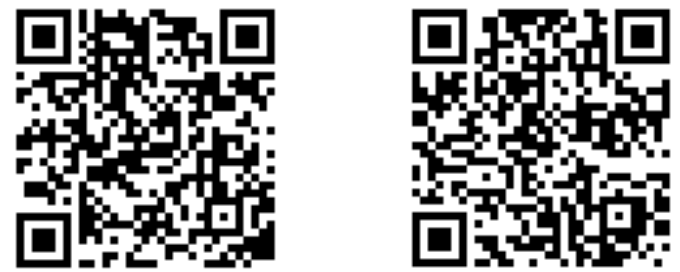

Artur Alexandrovich Blagorodov Institute of Entrepreneurship and Service sector (branch)

DSTU

bachelor, g. Shakhty

blaghorodov@list.ru

Dmitri Olegovich Bordukh

Institute of Entrepreneurship and Service sector (branch)

DSTU

bachelor, g. Shakhty bordukh95@bk.ru

Angelina Vladimirovna Kopylova Institute of Entrepreneurship and Service sector (branch)

DSTU

bachelor, g. Shakhty angelinakopylova22121999@mail.ru

Vladimir Timofeevich Prokhorov ISOP (f) DGTU

Doctor of technical sciences, professor, professor of the department "Designing, technology and design", Shakhty prohorov@sssu.ru

Igor Mikhailovich Maltsev Institute of Entrepreneurship and Sevice sector (branch) DSTU associate Professor, Ph. D.-m H., g. Shakhty

Tatyana Pavlovna Lopatchenko Isoip (f) DSTU associate Professor, Department of Natural Sciences, g. Shakhty

\title{
ABOUT THE POSSIBILITY OF A UNIVERSAL AND MULTI- FUNCTIONAL EQUIPMENT ON THE BASIS OF NUMBERS PLANT FOR MANUFACTURE OF IMPORT-SUBSTITUTING PRODUCTS
}

Abstract: The article considers the main ways of development of competitive and marketable products, which are possible only if managers are professionally trained and politically responsible for its performance.in the article the theoretical foundations to find innovative technological solutions for the production of import of children's shoes at the enterprises of the Southern Federal District and the North Caucasian Federal District regions. This task will trigger the removal of the deficit and improve the social situation of the population in these regions. in the article the theoretical basis of the evaluation of the effectiveness of innovative technological solutions for the production of import of children's shoes at the enterprises of the Southern Federal District and the North Caucasian Federal District regions. Representation of the correlation of the range of products and innovative solutions adopted for the production of these products. in the article the theoretical basis of the evaluation of the effectiveness of innovative 


\begin{tabular}{|c|c|c|c|c|c|c|}
\hline \multirow{4}{*}{ Impact Factor: } & ISRA (India) & $=3.117$ & SIS (USA) & $=0.912$ & ICV (Poland) & $=6.630$ \\
\hline & ISI (Dubai, UAE & $=0.829$ & РИНЦ (Russia & $=0.156$ & PIF (India) & $=1.940$ \\
\hline & GIF (Australia) & $=0.564$ & ESJI (KZ) & $=8.716$ & IBI (India) & $=4.260$ \\
\hline & JIF & $=1.500$ & SJIF (Morocco & $=5.667$ & OAJI (USA) & $=0.350$ \\
\hline
\end{tabular}

technological solutions for the production of import of children's shoes at the enterprises of the Southern Federal District and the North Caucasian Federal District regions.

Key words: competitiveness, relevance, innovation and innovative activity, economic policy, professional solutions, professional trained managers, profit, profitability, high efficiency TEP. competitiveness, demand, import substitution, competitive potential, product range, children demand comfort and safety.

Language: English

Citation: Blagorodov, A. A., Bordukh, D. O., Kopylova, A. V., Prokhorov, V. T., Maltsev, I. M., \& Lopatchenko, T. P. (2019). About the possibility of a universal and multi-functional equipment on the basis of numbers plant for manufacture of import-substituting products. ISJ Theoretical \& Applied Science, 06 (74), 768-793. Soi: http://s-o-i.org/1.1/TAS-06-74-88 Doi: crossef https://dx.doi.org/10.15863/TAS.2019.06.74.88

\section{Introduction}

All policy and has always been understood as an activity in the public interest. Political responsibility in a democratic society-furnished - the highest form of expression of professionalism. Failure of political promises and declarations - indicates either a failure to engage in politics, or the use of political governance in the private interest. 85 years ago for obvious consciousness and it was as such in practice. In vain, speaking of cruelty IV Stalin, forget that every flaw in the policy is reflected in the position of the people, not the politicians, managers, consultants, advisors [1].

Economic science emerged and developed in the context of politics, as political economy. Today, economists in the policy are not guided by political economy and economic policy. Instead of investing in the development of production are hiding money in foreign banks, reduced funding for education and selfeducation, increasing the number of the poor, do not index pensions, denied aid to farmers, etc. "Manilovs' nineties changed" Plyushkin "tenths.

Progress does not happen without a derogation, the slowdown in the movement of recessions. Policy aims to active, targeted actions to help to overcome the obstacles encountered in the development. Politicians must stay ahead of the economic movement and guide it, to stimulate domestic economic factors political leverage, to clear the way to economic efficiency. Instead, the politicians continue to bind development plans to the price of oil, the ruble amount of European and American currency, referring to the integration trends in the world and globalization. [2]

Integration of transnational relations - an objective reality, but for all its objectivity, it does not deny the specifics of national economic progress. Moreover, the integration objective is designed to contribute to national development. Why do we then do not get how it should be? This question arises from the logical comparisons policy in strengthening the defense, restore the international prestige of the country in the most difficult circumstances, the formation of a new world architectonic to the fact that year after year the Russians observe and fully feel the in the rest of the economy - we do not accidentally the two governments? The second "shakes gas and inhibits" simultaneously.

\section{Main part.}

Prolonged recession in the Russian economy has: two ways of explanation. The first - the people have lost the ability to work well, squandered "human capital", the second - control helpless. The media claim that politicians know their stuff, keep things under control, take the necessary measures and promise to change for the better in the near future. Hence, the reason is the poor performance of the performers and the unfavorable world market conditions.

How much you have to be naive to planning economic policies, based on sincerity, selflessness, compassion competitors? The Russian president has long said that our Western partners do not want to strengthen Russia, they need obedient Russia, such as the Baltic republics of the former USSR. Do not grieve like the politicians who are responsible on the economy, but, according to Aristotle, forced to admit: "Friends of the East too canny" - meaning "Plato is my friend, but truth is more expensive." They will help us at least benefit from this assistance.

It is time to realize that all the economic and political alliances in the modern world space - is an attempt to achieve national win in an environment of transnational relations, ie, partners can count on until it is advantageous cooperation. Which implies the conclusion - you need to stand face to its economy. Only in this way, even with a lot of stress, it is able to solve their problems. There is, for example, these objective reasons that would justify the decline in production for over a quarter century in the light industry.

The problems of agriculture and light industry is not in their specificity, they have always been political. In the United States, Europe, farmers have a lot of our problems. The difference is that there is a farmer - a national problem among the most important, fundamental. Its important for consideration of the existence of politicians. On how the policy is to promote a settlement, estimated public places policies. Farmer and politician linked economic policy. They balance on one taut economic stress "rope" viability.

Nothing similar in Russia. Recall the story of the last of Agriculture Ministers. In the Soviet Union there was the Ministry of Light Industry, which emphasized the importance of the industry. What prevents the 


\begin{tabular}{|c|c|c|c|c|c|c|}
\hline \multirow{4}{*}{ Impact Factor: } & ISRA (India) & $=3.117$ & SIS (USA) & $=0.912$ & ICV (Poland) & $=6.630$ \\
\hline & ISI (Dubai, UAE & $=0.829$ & РИНЦ (Russia & $=0.156$ & PIF (India) & $=1.940$ \\
\hline & GIF (Australia) & $=0.564$ & ESJI (KZ) & $=8.716$ & IBI (India) & $=4.260$ \\
\hline & JIF & $=1.500$ & SJIF (Morocce & $=5.667$ & OAJI (USA) & $=0.350$ \\
\hline
\end{tabular}

importance in terms of import declarations and to develop its own production to restore equality in industrial control. "Calico edge" without light industry still that his own nature without birch groves or lyric poetry without creativity Esenin.

Reformers 1990 fate Homeland domestic and industrial care less identity. They lined up on the ease of business to maximize profits and walrus placed away from their ancestral lands. Light industry has traditionally been a difficult problem to manage. Managers need to be, above all, patriots, or light industry did not raise. understanding of "long money" national importance it is also necessary. Compensating the difficulties to become demand stability.

What is the policy ineffectiveness in the economy end of last and the beginning of the new century? This question №1, and we are talking not so much about who is to blame. We are interested in the essence of the political paradigm, developed by those who turned out to be "at the helm". Question №2 - that should be changed and how, apparently, it is necessary to do to raise the national industry, clothing, footwear, leather goods, textiles, accessories, not least? [3]

The answer to the question №1 simple - no one was going to develop a paradigm of economic policy aimed at a radical transformation of the basis. reforming method (not without help from) decided to choose from ready-made designs. For a model is proposed to take the Swedish experience, the Polish "shock therapy" reforms in Portugal, Argentina. So innovators, scientists brave and wise organizer as Gaidar, Chubais, Koch, Burbulis not come up with the idea, which usually begins to charge the owner - than I have, something to copy.

Politics is not done according to the state of feeling. Like it or not - the level of consumer perception of the world. With this approach to the "political kitchen" be harmful. Economic policy does not fit the "good" or "bad", "effective" or "ineffective". She has a right to be called a "useful" or "harmful". Too high price of such policies, respectively, and the responsibility is not limited to professional form. Politics is politics. Apolitical and unprofessional to make politics a source of income of their own.

Whatever the economic situation did not develop extremely dangerous absolute value of economic criteria, give them the property of universality. Engels sharply opposed the attempts to bring the teachings of Karl Marx on the social development of "economic materialism", "economic determinism." Economic basis - the basis of social organization, but not systemforming factor of its improvement.

The most difficult part of the economic reforms - to achieve satisfaction in society national product distribution. From this meeting, rather than the form of ownership depends on the health of society. And we come to an important conclusion - the quality of the reform is estimated not by the changes, and the ability to make social life stability characteristics.

Integration, globalization - not a panacea for development. They do not cancel the competition in which the winners are not alone. More losers. Hence the relevance of the old truth, the meaning of which became clear in the dialectic. Movement in all conditions becomes a self-movement. Chinese rationally closed themselves and won. The victory ensured them: Eastern cautious and skeptical attitude toward unification. They used to have realized that integration and globalization are varieties of "pyramids" and conditionally useful for national development. From the side it might seem that Chinese reformers rejected the mentality of the curse: "you to live in a time of change." From the inside it looked traditionally - politicians do not betray a sharp movement on a national scale, in a hurry, but with constant reference to the actions of the state economic structure, reforms in the economy subordinated the traditional political dominants not repented and tried to please. About any economic shocks no one seriously thought. Finance as the circulatory system of the economic organism took "echinoid state gloves", entered the tightening of economic and corruptionrelated crimes, equating to a lot of them to dangerous actions against the State, did not come up with new games - update available, as always paid special attention to personnel policy. The Chinese have taken into account the experience of the Soviet party "growing" frame, which is based on the principle of steady progress, depending on the efficiency of business and lifestyle. Finance as the circulatory system of the economic organism took "echinoid state gloves", entered the tightening of economic and corruption-related crimes, equating to a lot of them to dangerous actions against the State, did not come up with new games - update available, as always paid special attention to personnel policy. The Chinese have taken into account the experience of the Soviet party "growing" frame, which is based on the principle of steady progress, depending on the efficiency of business and lifestyle. Finance as the circulatory system of the economic organism took "echinoid state gloves", entered the tightening of economic and corruption-related crimes, equating to a lot of them to dangerous actions against the State, did not come up with new games - update available, as always paid special attention to personnel policy. The Chinese have taken into account the experience of the Soviet party "growing" frame, which is based on the principle of steady progress, depending on the efficiency of business and lifestyle.

The market for light industry grows at the expense of social and cultural progress, in particular through the development of professional sports, the increase demand for those who choose the sport as a way to a healthy lifestyle. At the end of 2015, "Sport Express" newspaper published an interview with the 


\begin{tabular}{|c|c|c|c|c|c|c|}
\hline \multirow{4}{*}{ Impact Factor: } & ISRA (India) & $=3.117$ & SIS (USA) & $=0.912$ & ICV (Poland) & $=6.630$ \\
\hline & ISI (Dubai, UAI & $=0.829$ & РИНЦ (Russia & $=0.156$ & PIF (India) & $=1.940$ \\
\hline & GIF (Australia) & $=0.564$ & ESJI (KZ) & $=8.716$ & IBI (India) & $=4.260$ \\
\hline & JIF & $=1.500$ & SJIF (Morocco & $=5.667$ & OAJI (USA) & $=0.350$ \\
\hline
\end{tabular}

chairman of the Russian Outdoor Group A. Grebtsova. "The market for outdoor-goods serves climbing, hiking, extreme sports, special forces, rescue teams, service and polar forces. This direction, which require a heavy-duty, freezeproof, waterproof equipment that meets the new international safety and comfort standards "[4]. A. Rowing reported interesting details, in particular, he compared the technological base of production of quality products in the Russian Federation, Europe and Asia. We are "somewhat behind" in his estimation, from the Asian potential, but with Europe "we can accurately compete ... in Russia there are about 30 (!) of companies that are good at sewing." After the ban of imports for state procurement and defense contracts share materials from member countries of the Customs Union, delivered to law enforcement agencies of the country increased from $30 \%$ in 2011 to $83 \%$ in 2015 . In 2015, the trend of increasing the share of countries in the production of materials KPES used for the production of ware property should be around $85-90 \%$. Reversal of state order in the direction of domestic production opens possibilities for allied chemical industry (raw yarn, fittings, membranes, insulation). Grow production fabric, tailoring, it will pull the development of equipment. A. Grebnev believes that it is important to [5] to consolidate the results achieved: but with Europe "Just we can compete ... there are about 30 (!) of the companies in Russia, who are good at sewing."

make clear the importance of large retail chains purchase and placement of goods produced in Russia, of course, in view of their good quality;

place the first orders for the production of those "who have stood up and knows how to sew." They have proved their worth;

$\checkmark$ assist companies to obtain a European certification materials, otherwise they are not interested in foreign companies, and the goods produced in our country, does not get to the West;

to actively support the company's collective stands at international exhibitions;

] represent such enterprises subsidies on loans for the purchase of raw materials. These loans Ratio of total lending should be from 50 to $85 \%$;

$\square$ to liberate the modern import equipment from import duties and VAT. Machines used in sewing workshops, $90 \%$ imported;

$\square$ implement preferential leasing.

As you can see the program A. Grebneva organizes basic and the primary steps in the direction of the light industry to ensure that the return to its former value. However, Heraclitus was right in saying that you can not step twice into the same river. The rise of light industry should be made to the new technological, economic and legal framework.

The absence of effective and innovative solutions in enterprises SFD and North Caucasus Federal District regions are a deterrent to meet the demand for children's footwear consumers in these regions, which provokes their dissatisfaction and the formation of children abnormalities [1].

Considering the traditional technological processes of production of leather goods, which today are the sources of the negative impact on the environment and human health, it can be stated that practically each of technological operations in varying degrees, is environmentally hazardous. The greatest significance of adverse effects on human render operation process related to the use of parts of top and bottom of footwear, made from the auxiliary materials comprising in its composition toxic substances. In the first place - is, of course, mortar adhesives containing in its composition 78 - 80\% solvents (acetone, ethyl acetate, benzene). And given that at present more than $80 \%$ of shoes manufactured using auxiliary materials,

Use of chemicals in footwear production improves aesthetics, moisture barrier, friction and other properties of the shoe, thus enhancing the competitiveness of products. In recent years, under the influence of chemicalization word appear fundamentally new kinds of shoes, such as sports, which is manufactured by molding a plastic outer shell with inserted in her inner sock. Perhaps this is the future of shoes that will radically change its entire production technology, will lead to full automation of the process.

Methods of chemical technology are generally classified on several grounds. For example, the physical state of the material during forming polymers:

- are in a plastic condition - injection molding, extrusion, pressing, sintering, etc .;

- are in the rubbery state - vacuum, blow molding, hot stamping, etc ;

- in the solid state (crystalline or vitreous, is taken into account the ability to exert a forced high elasticity - stamping at room temperature, rolling, etc.), Etc .;

- using the solutions and dispersions - plastisols rotational molding, injection molding plastisol, dipping a molding;

- using a oligomers - a liquid molding method, dipping and others.

By the method of mouldable materials techniques can be classified as recycling:

- thermoplastics - injection molding, extrusion, blow molding and evacuation;

- zhelatiniruemyh pastes - dipping, casting, injection molding;

- rubbers and thermosets - pressing, injection molding;

- polyurethanes - casting, injection molding.

As a result of the use of chemicals contributes to the growth of labor productivity and reduce the complexity of the manufacture of leather products. It is obvious advantages of chemical fastening methods 


\begin{tabular}{|c|c|c|c|c|c|c|}
\hline \multirow{4}{*}{ Impact Factor: } & ISRA (India) & $=3.117$ & SIS (USA) & $=0.912$ & ICV (Poland) & $=6.630$ \\
\hline & ISI (Dubai, UAE & $=0.829$ & РИНЦ (Russia & $=0.156$ & PIF (India) & $=1.940$ \\
\hline & GIF (Australia) & $=0.564$ & ESJI (KZ) & $=8.716$ & IBI (India) & $=4.260$ \\
\hline & JIF & $=1.500$ & SJIF (Morocce & $=5.667$ & OAJI (USA) & $=0.350$ \\
\hline
\end{tabular}

(adhesive, vulcanization, stitch-injection) to traditional (rantovoy - stitching, nailing - pin).

Competitors is a complex problem because it often happens that in the interests of a competitor condition can cause another to waver. However, competitors are joining forces to combat the threat of the emergence of innovative third-party products, for the successful completion of the life cycle and to leap forward on the basis of new technologies. Competing organizations form alliances to accelerate technological progress and development of new products, to enter new foreign markets or to find a wide range of new possibilities. Sometimes cooperation determined by the need to develop common standards, creating a common system service, etc.

For profit entity must keep a track of the share of the manufacturing costs of the proposed release mnogoassortimentnyh shoes.

Filling processes for the production of competitive and popular footwear for consumers SFD and North Caucasus Federal District regions is costly. Using the universal and multi-functional equipment generates a workflow in a way that allows to make the whole product range of high quality shoes and with different price niche.

But in this case it is necessary to find a solution that would allow the manufacturer to have a tool to assess the effectiveness of innovation processes. Such a solution is possible if the in each case be used to assess the effectiveness of such a coefficient, whose value as a coefficient of concordance (W), to be applied within the $0 \leq K_{э \phi} \leq 1$. If its value tends to unity, it means that the manufacturer was able to find the best solution, if its value goes to zero - that requires an analysis of the reasons for this unsatisfactory outcome and troubleshooting, provoked obtain such a result [3].

For efficient operation of domestic enterprises for the production of competitive children's footwear appropriate to provide for the use of innovative flexible manufacturing processes, the use of universal and multi-functional equipment, a variety of methods for attaching the shoe bottom, drill shoe manufacturing TEHOSNASTKA, fittings, production of auxiliary materials, which will significantly reduce the cost of its production and improve the competitiveness not only in the markets of the South the second and the North - Caucasian Federal District (SFD SFD), but also on the domestic markets of other regions of Russia, guaranteeing it a steady supply and implementation, thereby providing less painful and more efficient replacement of one shoe model to another, ensuring the formation of new jobs in within small and medium-sized enterprises,

The strategy of production of competitive products from the skin will be organized production of shoes with not only mechanized innovative processes using nanotechnology, but that is especially in demand for SFD and North Caucasus Federal District - the use of manual labor, which is due to the desire of manufacturers to meet the demand for exclusive products not only for the elite, but also for consumers.

When the labeling methods of chemical technology leather products must be assumed that they are associated with the processes of processing, molding and finishing of various polymeric materials such as natural and artificial leather, plastics, elastomers, film, and textiles, cardboard, wood, and so on. $n$. The basis of these methods are those processes of chemical technology such as pressing, gluing, welding, molding, trim, and others.

The correct definition of quality, consistency, and quality management system gives the manufacturer a decisive advantage in the competition for the consumer. It would seem that everything is simple, but the simplicity of equally ingenious and deceptive. The overall plan to solve the problem determines the motion vector puts factorial priorities for action - not more.

To get the desired profit in the conditions when the prices of footwear and production volumes are dictated by the market, the company always has to choose what - and how much to produce the products in terms of the cost of its production and taking into account the solvency of potential buyers.

A high quality, competitive footwear is a prerequisite for high-efficiency operation of the shoe business.

An important criterion for the shoe market competitiveness is its cost with a corresponding its quality and purchasing power of the population.

The main criterion of the viability and profitability of the enterprise is profit, to increase profits in the first step is to reduce the cost of shoes.

The ratio of the changes in the calculation of each article costs depend on changes in the total cost, which includes all costs of production and sale of shoes.

An important factor affecting the level of costs in the production of shoes is to change the range and production process.

The choice of technology that can effectively implement the targets set in the conditions of tough competition, provide a guarantee that the developed range of shoes will be chosen by the buyer and will enable the company to maximize profits. [4]

To solve this problem you need an injection molding method most commonly used, which ensures the production of the entire product range of high quality shoes under different profitability of certain types of footwear to meet the demand of different population groups.

Reducing restrictions on the use of materials for shoe uppers in the manufacture of shoes injection method was created today, and most importantly, in 


\begin{tabular}{|c|c|c|c|c|c|c|}
\hline \multirow{4}{*}{ Impact Factor: } & ISRA (India) & $=3.117$ & SIS (USA) & $=0.912$ & ICV (Poland) & $=6.630$ \\
\hline & ISI (Dubai, UAI & $=0.829$ & РИНЦ (Russia & $=0.156$ & PIF (India) & $=1.940$ \\
\hline & GIF (Australia) & $=0.564$ & ESJI (KZ) & $=8.716$ & IBI (India) & $=4.260$ \\
\hline & JIF & $=1.500$ & SJIF (Morocco & $=5.667$ & OAJI (USA) & $=0.350$ \\
\hline
\end{tabular}

the future prerequisites for the production of the entire product range from acceptable to the consumer price niche, if the requirements are met for filling production of innovative technological solutions and "patchwork" in order to reduce the cost of production of the most popular shoes for children in all the product range.

The cost of production of the shoe constitute the largest share in the cost of raw materials and basic materials, followed by salaries and depreciation.

Footwear injection method is possible with the use of artificial and synthetic leather and textile materials, which will reduce costs and make big profits because range of these materials is cheaper and much more diverse [5].

Another factor reducing the cost is to reduce the labor intensity, which is provided by an injection method, which determines the cost of the article "The main and additional wages of production workers with insurance premiums to non-budgetary funds" .For implementation injection method requires the use of more expensive equipment (injection molding machine) that affect the increase in the cost of the shoe by increasing the costs of depreciation and maintenance fund, but the risk is justified.

Implementation of the authors of the proposed measures would lead to the elimination of the deficit on the domestic children's shoes, making it not only and not so much competitive, and relevant, but the main thing - a safe and comfortable for the child's foot, guaranteeing him protection against the formation of pathological abnormalities.

Increasing demand and competitiveness shoe enterprises is one of the most important areas of real economic growth, both in Russia and in the regions of the Southern Federal District and the North Caucasian Federal District. Therefore, the current situation has led to the need for the release of the original range of products, taking into account national and climatic characteristics of these regions and improving the metrological assurance testing of footwear, leather and clothing accessories to enhance the quality of products as part of its import.

In recent years, the absolute increase in the production of leather shoes is growing, at shoe factories updated range of footwear based on public demand, increases the release of the model and insulated footwear, footwear with uppers of leather and white patent leather natural, elegant shoes for the children. The country's transition to market economy has led to a sharp deterioration of the situation in the footwear industry of Russia in connection with the reduction of solvent demand of the population, deepening inflation, non-payments crisis, which, in turn, caused the imbalance in the production and circulation.

When the organization of sales of produced shoes do not forget that in the South and the North Caucasian Federal Districts were and are so-called "hot spots", which are the territories with the crisis economic situation and the negative political position.

Filling processes for the production of competitive and popular footwear for consumers SFD and North Caucasus Federal District regions is costly. Using a universal and multi-functional equipment generates manufacturing process thus allowing to make the whole product range of high quality footwear and with different price niche [1].

The formation range precedes the development of enterprise product line concept. It is aimed to build an optimum assortment structure, commodity supply, with a basis accepted, on the one hand, the consumer demands of certain groups (segments), and with another - the need to ensure the most efficient use of enterprise commodity, technological, financial and other resources in order to manufacture products at low cost [2]. Assortment concept is expressed in the form of a system of indicators characterizing the possibility of optimal development of the production range of this type of goods. These indicators include: the diversity of species and varieties of goods (taking into account the typology of consumers); the level and frequency of updating of assortment;

- definition of current and future customer needs, analysis of ways to use the features of the footwear and consumer behavior in the relevant market;

- evaluation of existing analogues of competitors;

- critical evaluation of products now manufactured in the same range as in items 1 and 2, but with the position of the buyer;

- issues, what products should be added to the range, and which are excluded from it because of changes in the level of competitiveness; whether to diversify production at the expense of other areas of the enterprise production beyond its existing profile.

- consideration of proposals for the creation of new models of shoes, the improvement of existing ones;

- Development of specifications for new or improved models in accordance with customer requirements;

- explore the possibilities of production of new or improved models, including price issues, cost and profitability;

- testing (testing) Shoe considering potential consumers in order to determine their admissibility on the basic parameters;

- development of specific recommendations for the company's production divisions regarding quality, style, price, name, packaging, service, etc. in accordance with the results of tests carried out to confirm the acceptability of the product characteristics or the necessity of predetermining the change;

- assessment and revision of the entire range. [3]

The absence of effective and innovative solutions in the enterprise SFD and North Caucasus Federal District regions are a deterrent to meet the 


\begin{tabular}{|c|c|c|c|c|c|c|}
\hline \multirow{4}{*}{ Impact Factor: } & ISRA (India) & $=3.117$ & SIS (USA) & $=0.912$ & ICV (Poland) & $=6.630$ \\
\hline & ISI (Dubai, UAI & $=0.829$ & РИНЦ (Russia & $=0.156$ & PIF (India) & $=1.940$ \\
\hline & GIF (Australia) & $=0.564$ & ESJI (KZ) & $=8.716$ & IBI (India) & $=4.260$ \\
\hline & JIF & $=1.500$ & SJIF (Morocco & $=5.667$ & OAJI (USA) & $=0.350$ \\
\hline
\end{tabular}

demand for children's shoes consumers in these regions, which provokes their dissatisfaction and the formation of children's education abnormalities.

Use of chemicals in footwear production improves aesthetics, moisture barrier, friction and other properties of the shoe, thus enhancing the competitiveness of products. In recent years, under the influence of application of chemicals fundamentally new kinds of shoes, such as sports, which is manufactured by molding a plastic outer shell with inserted in her inner sock.

For profit entity must keep a track of the share of the manufacturing costs of the proposed release multiassortment shoes.

This is only possible if the business leaders will implement advanced technological solutions generated through the use of multi-functional and universal equipment, and it must be remembered that the very innovative technological solutions should not be expensive, that is, on the one hand to ensure stability of the enterprise technical and economic indicators and ensuring they demand not only in the sales regions of the Southern Federal district and the North Caucasian Federal district markets, but in other regions of Russia and districts to be attractive $\mathrm{E}$ for foreign users. But on the other hand, consumers should have a choice to compare price niche on offering products with similar foreign companies, and always take precedence. This will be possible when forming production,

Wider application of injection method will allow enterprises in market conditions to obtain a profit amount, which will allow them not only to firmly hold its position in the markets for their shoes, but also to ensure the dynamic development of its production in a competitive environment, it is especially important in the production of the entire product range children's shoes.

It will be appreciated that the chemical technology methods leather products differ significantly fewer operations compared to conventional thread: 50 ... 70 process cycle operations instead of $150 \ldots 180$ in the case of manufacturing shoes by attaching rantovoy.

Another method - by dipping - it is possible to manufacture shoes, combining creation shoe upper material while forming shoe itself. It is also a completely new progressive method of chemical technology products from the skin.

When the labeling methods of chemical technology leather products must be assumed that they are associated with the processes of processing, molding and finishing of various polymeric materials such as natural and artificial leather, plastics, elastomers, film, and textiles, cardboard, wood, and so on. $n$. The basis of these methods are those processes of chemical technology such as pressing, gluing, welding, molding, trim, and others.
In a market economy to survive in an everchanging economic environment, footwear enterprises should focus on the target audience:

- increase the amount of profit as a result of growth in the volume of sales of products, lowering its costs and improving product quality.

To get the desired profit in the conditions when the prices of footwear and production volumes are dictated by the market, the company always has a choice - what products and how much to produce in terms of the costs of its production and taking into account the solvency of potential buyers.

A high quality, competitive footwear is a prerequisite for high-efficiency operation of the shoe business.

An important criterion for the shoe market competitiveness is its price corresponds to its quality and purchasing power of the population.

The main criterion of the viability and profitability of the enterprise is profit, to increase profits in the first step is to seek to reduce the cost of shoes.

The ratio of the changes in the calculation of each article costs depend on changes in the total cost, which includes all costs of production and sale of shoes.

An important factor affecting the level of costs in the production of shoes, a change in the range and modernization process.

The choice of technology that can effectively implement the targets set in the conditions of tough competition, provide a guarantee that the developed range of shoes will be chosen by the buyer and will enable the company to maximize profits.

To solve this problem, again, we must be the most widely used injection molding method, which ensures the production of the entire product range of high quality shoes under different profitability of certain types of footwear to meet the demand of different population groups.

For profit entity must keep a track of the share of the manufacturing costs of the proposed release multiassortment shoes [4].

The main unique aspects of competitive advantages of enterprises are:

- the creation and expansion of a permanent database of key partners;

- the formation of the necessary technical resources (computers, peripherals and software);

- organization of activity units and individual managers to manage relationships with stakeholders;

- development and updating of plans for cooperation with key partners, in view of their business and personal features;

- regular audit of managers to manage relationships with partners in the context of evaluating the following indicators: 


\begin{tabular}{|c|c|c|c|c|c|c|}
\hline \multirow{4}{*}{ Impact Factor: } & ISRA (India) & $=3.117$ & SIS (USA) & $=0.912$ & ICV (Poland) & $=6.630$ \\
\hline & ISI (Dubai, UAI & $=0.829$ & РИНЦ (Russia & $=0.156$ & PIF (India) & $=1.940$ \\
\hline & GIF (Australia) & $=0.564$ & ESJI (KZ) & $=8.716$ & IBI (India) & $=4.260$ \\
\hline & JIF & $=1.500$ & SJIF (Morocco & $=5.667$ & OAJI (USA) & $=0.350$ \\
\hline
\end{tabular}

- number of meetings with partners, the number of trained commercial proposals, the number of contracts, the speaker volume of deliveries of production attributable to each partner;

- Regular market research in partnership in order to identify changes in the structure and character of preferences when selecting the range.

In conclusion I would like to once again draw the attention of manufacturers that use the injection method will allow the company to market conditions to obtain a volume of income that will allow them not only to firmly hold its position in the shoe sales market, but also to ensure the dynamic development of its production, in a competitive environment , especially in demand in the production of the entire product range of children's shoes.

Therefore, the above-mentioned aspects, at the appropriate level of study, will allow the company to create unique competitive advantage - the implementation of a system of relations with the stakeholders to produce competitive and sought after shoes for children.

Main place among the attributes of any enterprise takes the name of the company goes public. We know the company not by a legal phrase that is enshrined in the relevant registration documents (yes it is unknown to wide range of customers), and on the brand's products. Thus, the rare consumer knows that the shoes of the Trading House "Squirrel" - is Ralf Ringer. The producers of the Southern Federal District for the most part the name (brand name) is absent.

There are several methods of forming the name, logo and trademark of birth [1].

The most common way - the choice of a proper name. Typical for the fashion houses (class "luxury" goods) - the founder of the company name CHRISTIAN DIOR, CHANEL, GIVENCHY, YVES SAINT LORAN etc. Unique taste, bright style of expressing the personality of artists in their works, later asking things issued under this name, high status. This technique has become necessary if the company creates an individual or family and you want to emphasize the personal role of the owner, and build on its reputation and the reputation of the company's policy. With this approach, the role of the individual is invaluable. Last name must be the guarantor of the quality of products and business management. Accordingly, if the owner of the image not just directly related to the company's image, but also has the primary emotional burden [2].

Another way - the commercial name of the company is based on the acronym made up of the first letters of the official title. This achieves conciseness name and the ease of pronunciation and memorizing respectively. Can clearly be seen that it is an abbreviation - a great tool for getting a logo - the company LVMH / Louis Vuitton Moet Hennessy /. The same method of recourse companies positioning their products in the class of «Bridge better», representing the second line of the famous houses; in the title is a link to the artist's name, associated with its line of luxury "souture» and «preta - porte de lux» and an abbreviated reduction. For example, Mani (Armani), DKNY (Donna Karan New Your), CK Jeans (Calvin Klein).

Second - much less common in the fashion industry - education it is the United root fragments of a few words, is not necessarily present in the company's name. But in this case, the desirable association with the profile of the company. The requirement, like any other group names and unusual euphony.

The third way - the formation of new words, do not like the existing meaningful words, but is associated with positive concepts. Most often, the positioning of these companies is connected with the class bridge middle, bridge low and moderate mass clothing class and buget.

The fourth method is the logo. Purpose of the $\operatorname{logo}$ in the fashion industry - this instant brand awareness. Logo - a symbolism that replaces the name or is a graphic interpretation. Interestingly, in the world of fashion logo has become so much a part of the design of clothing and footwear.

Consumers in the market does not appear monolithic community. When buying shoes, they are guided, first of all type of footwear and price.

For example, when choosing a buyer of women's boots into account the seasonality of the shoe, its age features and type of work, it is important attributes will then be the appearance of the shoe: matching fashion trends, colors, materials, top and bottom, as well as a constructive solution models. Buyers also prefer brand. It is an offer of shoes to the consumer in specialty stores or departments will provoke an increase in sales in an uncertain demand. And if we seller, having a well thought-out principles of presenting advantageous properties of each design women's boots, and, guessing the mood and the possibility of women customers for its reasoned matters when choosing a model, be able to realize it is the desire, in any case, the buyer will leave satisfied that its interests fully satisfied,

The elderly love comfort and coziness. Both the seller and the buyer - the representative of the beautiful half - of course, turn their attention to the model, if it is nice to be worn in the snowy winter, since it must be made of soft nap leather - suede and have a molded sole with large tread, as will very comfortable and provide them comfort at any time during her socks .. at the same time it must be affordable.

Business woman, aged 45 and 45 and residing in the vanity, of course, will give preference to models made of natural materials, low-heeled, low-key accessories, creating imposed the comfort in their daily lives, while emphasizing their image and social status. 


\begin{tabular}{|c|c|c|c|c|c|c|}
\hline \multirow{4}{*}{ Impact Factor: } & ISRA (India) & $=3.117$ & SIS (USA) & $=0.912$ & ICV (Poland) & $=6.630$ \\
\hline & ISI (Dubai, UAI & $=0.829$ & РИНЦ (Russia & $=0.156$ & PIF (India) & $=1.940$ \\
\hline & GIF (Australia) & $=0.564$ & ESJI (KZ) & $=8.716$ & IBI (India) & $=4.260$ \\
\hline & JIF & $=1.500$ & SJIF (Morocco & $=5.667$ & OAJI (USA) & $=0.350$ \\
\hline
\end{tabular}

Assortment - the problem of specific products, their individual series, determining the relations between "old" and "new" products, products for single and serial production, "High" and "normal" goods, materialized goods or licenses and "know-how". When forming the price range there are problems of quality, warranty, service, whether the manufacturer is going to play a leadership role in the creation of new types of products or forced to follow other manufacturers. [5] points:

Forming range includes the following main

1. Determining the current and future customer needs, analysis of ways to use the features of the footwear and consumer behavior in the relevant market;

2. Evaluation of existing analogues of competitors;

3. A critical evaluation of products now manufactured in the same range as in items 1 and 2, but with the position of the buyer;

4. Addressing what products should be added to the range, and which are excluded from it because of changes in the level of competitiveness; whether to diversify production at the expense of other areas of the enterprise production beyond its existing profile.

5. Consideration of proposals for the creation of new models of shoes, the improvement of existing ones;

6. Development of specifications for new or improved models in accordance with customer requirements;

7. The study of the production capacity of new or improved models, including price issues, cost and profitability;

8. Testing (testing) Shoe considering potential consumers in order to determine their admissibility on the basic parameters;

9. Development of specific guidelines for the production of the enterprise regarding the quality of units, style, price, name, packaging, service, etc. in accordance with the results of tests carried out to confirm the acceptability of the product specifications or predetermining the need to change them.

10. Assessment and review of the entire product range. [6]

Planning and assortment management - an integral part of marketing. Even a well-designed marketing and advertising plans will not be able to neutralize the consequences of mistakes made earlier in the planning range.

The optimum range of the structure should ensure maximum return on the one hand and sufficient stability of the economic and market indicators (eg sales volume), on the other hand.

Achieving the highest possible profitability is ensured by continuous monitoring of economic indicators and timely decisions on the adjustment range.
Stability of marketing performance is ensured, first of all, by continuously monitoring the market situation and timely reaction to the changes, or the adoption of pre-emptive action.

In addition, it is important that different products were not too many. For the majority of Russian companies, the potential for optimization of the range is still laid in a considerable reduction of the product range. Too large assortment of bad effect on economic performance - there are many positions that are on the volume of sales can not go even to break even. As a result, the overall profitability drops sharply. Only exception of unprofitable and low-profit products from a range of companies can give an increase in the overall profitability of $30-50 \%$.

In addition, a wide range of spray force, makes it difficult to competent offer of goods to customers (even the sales staff are not always able to explain the difference between a particular position or name), dispels the attention of end users.

It is appropriate to recall the psychology of perception of the information. The reality is that the average person is able to simultaneously absorb no more than 5-7 (rarely up to 9) of semantic constructs. Thus, the person making the choice, first selects the best 5-7 options on the basis of the same number of criteria. If the seller offers a large number of selection criteria, the buyer begins to feel uncomfortable and self-eliminates insignificant, from his point of view, the criteria. The same thing happens when you select the actual product. Now imagine what happens when a man in front of a hundred almost indistinguishable (for him) of the goods, and he needs to buy one. People behave in such a situation as follows: or do refuse to buy, so as not being able to compare a number of options, or they prefer what is already taken (or that sounds familiar). There is another category of people (about 7\%), lovers of novelties, which on the contrary will choose something that has not yet been tried.

Thus, from the customer's perspective (for relaxing the selection of measurable perception embodiment) range should consist of no more than 57 groups, 5-7 of names, i.e., the entire range in terms of perception optimally should consist of 25 - 50 titles. If the names of more than an objective, the output is only further classification.

It is generally accepted that a wide range of customer needs. This very wide range of often referred to even as a competitive advantage. But in fact it turns out that for a wide range of manufacturer - it's hundreds of types of products, and for the consumer 7 titles have more than enough.

Thus, the user need not wide range and variety required for it.

If the company professes approach a wide range, it is sufficient to carry out sales analysis, look at the statistics, to make sure that the sales leaders are $5-10$, on the strength of $15 \%$ of names, all other positions 


\begin{tabular}{|c|c|c|c|c|c|c|}
\hline \multirow{4}{*}{ Impact Factor: } & ISRA (India) & $=3.117$ & SIS (USA) & $=0.912$ & ICV (Poland) & $=6.630$ \\
\hline & ISI (Dubai, UAI & $=0.829$ & РИНЦ (Russia & $=0.156$ & PIF (India) & $=1.940$ \\
\hline & GIF (Australia) & $=0.564$ & ESJI (KZ) & $=8.716$ & IBI (India) & $=4.260$ \\
\hline & JIF & $=1.500$ & SJIF (Morocce & $=5.667$ & OAJI (USA) & $=0.350$ \\
\hline
\end{tabular}

are sold very little demand for them is insignificant, although costs differ little from cost of sales leaders. The situation turns out, when several items of "feeds" the whole wide range of businesses. And this is not always justified in terms of the completeness of the range (the favorite argument of sellers), that is, the presence of different items to cover the maximum possible options customer needs. In practice, it turns out that the fullness is completely ensured, even if the existing range of cut twice and even three times. The main thing in this case correctly classify all the goods and to ensure that to an assortment of products were submitted from every possible group that classification. Moreover, the more reason to classify the enterprise can allocate, the more balanced will be his decision. Thus, the classification of goods can be meet customer needs, according to the functional purpose of the goods, for the benefit of the enterprise.

In the current market conditions, the competitive environment and the direct interaction of Russian and foreign manufacturers addressing a combination of state and market competitiveness of governance is becoming a strategic resource economy SFD and North Caucasus Federal District regions. The world economy took place price competitiveness competitive quality levels, which increased its relevance to Russia's entry into the WTO. Therefore, an increase in the quality factor performance of the domestic production of shoes in the strategy of competition on the world markets is a long-term trend [1].

Especially urgent task of improving the competitiveness of footwear enterprises which, because of external factors (increased competition due to globalization, the global financial crisis) and internal (ineffective management) lost their competitive position in the domestic and foreign markets. In response to negative processes of regionalization processes are amplified in the external environment and create different network structures, one of which is an alliance of producers and the state.

Financial intermediaries - is a collection of a multitude of organizations, which includes, among others, banks, law firms, brokerage firms, investment advisor, pension funds, companies with mutual funds, and other organizations or participation of individuals who may be interested in investing in the enterprise. Credibility is especially important in dealing with the creditors. Disclosure of financial information helps build trust, as well as timely payments. Trying to establish your relationship with creditors and establish a relationship of trust, many companies invite their representatives to their boards of directors.

Currently there is no generally accepted method of evaluating the competitiveness of enterprises. A review of existing approaches to the assessment of the competitiveness of the enterprise allow to combine them into the following groups.
The first group of scientists economists It includes the approach to determining the competitiveness of enterprises, based on the identification of competitive advantages. This approach originated with the advent of strategic planning and development of the theory of competition. It allows to analyze the achieved competitive advantages, but does not accurately quantify the evaluation of the results and so can not be used for comparative analysis of the competitiveness of enterprises, analysis of the implementation plan to improve competitiveness, the dynamics of the competitiveness of enterprises.

The second group of economists It offers an assessment of competitiveness using a polygonal profile. It is based on the construction of vectors of competitiveness factors: the concept, quality, price, finance, trade, after-sales service, foreign policy, presale preparation. However, the authors do not specify how to evaluate factors such as the concept of foreign policy, pre-sale preparation and others., Combining them into one.

The third group of scientists and economists offer rating the company's competitiveness on the basis of the following factors: product range, price, image, service, packaging (registration), sales volume, market segment, supply and marketing policy, advertising and stimulate demand, ie calculation coefficient of efficiency of innovative technological solutions. The advantage of this approach e that he, in fact, assesses not only the marketing activities of the company, but also takes into account other important potential of the enterprise resources (innovation, management, finance, and others.). The authors proposed approach is a more weighty sum of factors, which take into account the weight of mutual in partnership.

The fourth group academic economists proposes to evaluate the competitiveness of the enterprise based on the product of the index of commodity mass index and the effectiveness of the object. The advantage of this approach is the fact that it is more powerful approach to the assessment, since it takes into account such important factors that determine the competitive advantages of the enterprise, as the level of organization and implementation of marketing in the enterprise, finance, export potential. In addition, most of the authors consider it important to develop methods for determining the efficiency factor producer, its competitiveness, and that will form the effectiveness of most of these partnerships.

The fourth approach can be attributed to the method proposed Fathudinovym RAWhich proposes to evaluate the competitiveness of the enterprise as a weighted sum of the core competitiveness of enterprise products in the various markets, taking into account the importance of markets. But this approach is not entirely fair, because firstly, the competitiveness of the organization identified with the competitive 


\begin{tabular}{|c|c|c|c|c|c|c|}
\hline \multirow{4}{*}{ Impact Factor: } & ISRA (India) & $=3.117$ & SIS (USA) & $=0.912$ & ICV (Poland) & $=6.630$ \\
\hline & ISI (Dubai, UAE & $=0.829$ & РИНЦ (Russia & $=0.156$ & PIF (India) & $=1.940$ \\
\hline & GIF (Australia) & $=0.564$ & ESJI (KZ) & $=8.716$ & IBI (India) & $=4.260$ \\
\hline & JIF & $=1.500$ & SJIF (Morocce & $=5.667$ & OAJI (USA) & $=0.350$ \\
\hline
\end{tabular}

product (different concepts), and secondly, it proposes to introduce the importance of foreign markets twice as large as the importance of the national markets. Third, the method of assessment RA Fatkhutdinova It ignores other important factors of influence on competitiveness - marketing, finance, innovation, management, human resources.

The fifth group Economists scientists suggests an approach based on a weighted evaluation of enterprise competitiveness. Integral indicator of the competitiveness of enterprises is determined according to the rules of linear convolution (evaluation factors of competitiveness of individual aspects of the company multiplied by the weight of individual factors in the total amount), then there is something very close to what is offered in this article the authors, namely the calculation of the coefficient of efficiency of innovative technological solutions[2,3].

So, the analysis of the theoretical and methodological aspects of the competitiveness of enterprises revealed numerous methods of estimation of the most competitive enterprises.

In this regard, the successful activity of the enterprise is determined by the degree of satisfaction of stakeholders interests, so to enhance the competitiveness and efficiency of the enterprise should take into account not only its own interests but also the interests of the parties concerned, ie its business partners.

It uses the term partnership, which creates the conditions for the effectiveness of the results of activity of the enterprise in the stakeholder theory.
Developing small and medium enterprises as an instrument of competition is necessary to form a system of marketing relationships with partners, a system based on a mutually beneficial long-term cooperation, which allows to reduce the time to make effective business decisions to ensure their competitiveness.

Therefore, taking into account the consideration of the methodological foundations of competitiveness of the enterprise, the methods of estimating and analyzing the competitiveness of footwear companies operating in the regions of the Southern Federal District and the North Caucasian Federal District, based on stakeholder theory, which are competitors for the production of an identical range of men's shoes.

In view of the analysis of the system of indicators to measure the competitive capacity of enterprises, JSC "Donobuv" and OOO "Leon" (Rostov-on-Don) An assessment of these companies will give the system of indicators to measure competitiveness factors enterprises offered above. The first important factor of competitiveness of the enterprise - the competitiveness of the goods (see Table 1) [4].

Let us analyze the second most important enterprise competitiveness potential - marketing effectiveness. The results of this potential represented in Table 2, where we point weighted evaluation on the test plants and the maximum score for these indicators.

Table 1. Evaluation of the competitiveness of enterprises

\begin{tabular}{|c|c|c|c|c|c|c|c|c|}
\hline \multirow{2}{*}{$\begin{array}{l}\text { Factors } \\
\text { competitiveness of the } \\
\text { enterprise }\end{array}$} & \multirow[t]{2}{*}{ Indicators } & \multirow{2}{*}{ 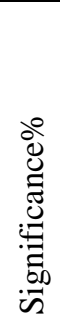 } & \multicolumn{2}{|c|}{ meaning } & \multicolumn{2}{|c|}{$\begin{array}{l}\text { Dimensionless } \\
\text { evaluation of } \\
\text { enterprise } \\
\text { competitiveness } \\
\text { indicators } \\
\end{array}$} & \multicolumn{2}{|c|}{$\begin{array}{l}\text { Weighted } \\
\text { evaluation of } \\
\text { the } \\
\text { competitiveness } \\
\text { indicators }\end{array}$} \\
\hline & & & $\begin{array}{l}\text { Ltd. } \\
\text { Leono } \\
\text { v }\end{array}$ & $\begin{array}{l}\text { ZAO } \\
\text { Donobu } \\
\mathrm{v}\end{array}$ & $\begin{array}{l}\text { Ltd. } \\
\text { Leono } \\
\mathrm{v}\end{array}$ & $\begin{array}{l}\mathrm{ZAO} \\
\text { Donobu } \\
\mathrm{v}\end{array}$ & $\begin{array}{l}\text { Ltd. } \\
\text { Leono } \\
\mathrm{v}\end{array}$ & $\begin{array}{l}\text { ZAO } \\
\text { Don } \\
\text { Shoes }\end{array}$ \\
\hline 1 & 2 & 3 & 4 & 5 & 6 & 7 & 8 & 9 \\
\hline $\begin{array}{l}\text { 1.Konkurento- } \\
\text { the ability of the product }\end{array}$ & $\begin{array}{l}\text { The weighted } \\
\text { average Product } \\
\text { Line competitive } \\
\text { goods, score }\end{array}$ & 40 & 3.05 & 3.49 & 0.61 & 0.69 & 24.4 & 27.92 \\
\hline \multirow[t]{2}{*}{$\begin{array}{l}\text { 2.Effektiv- } \\
\text { marketing Nosta }\end{array}$} & $\begin{array}{l}\text { Assessment of } \\
\text { the level of } \\
\text { partnership with } \\
\text { the interested } \\
\text { parties of the } \\
\text { enterprise, score }\end{array}$ & 10 & 2.85 & 3.05 & 0.71 & 0.76 & 7.10 & 7.60 \\
\hline & $\begin{array}{l}\text { Exceeding the } \\
\text { permissible level }\end{array}$ & 3 & 66,50 & 28,80 & 0.34 & 1.00 & 1.02 & 3.00 \\
\hline
\end{tabular}




\begin{tabular}{|c|c|c|c|c|c|c|}
\hline \multirow{4}{*}{ Impact Factor: } & ISRA (India) & $=3.117$ & SIS (USA) & $=0.912$ & ICV (Poland) & $=6.630$ \\
\hline & ISI (Dubai, UAE & $=0.829$ & РИНЦ (Russia) & $=0.156$ & PIF (India) & $=1.940$ \\
\hline & GIF (Australia) & $=0.564$ & ESJI (KZ) & $=8.716$ & IBI (India) & $=4.260$ \\
\hline & JIF & $=1.500$ & SJIF (Morocco) & $=5.667$ & OAJI (USA) & $=0.350$ \\
\hline
\end{tabular}

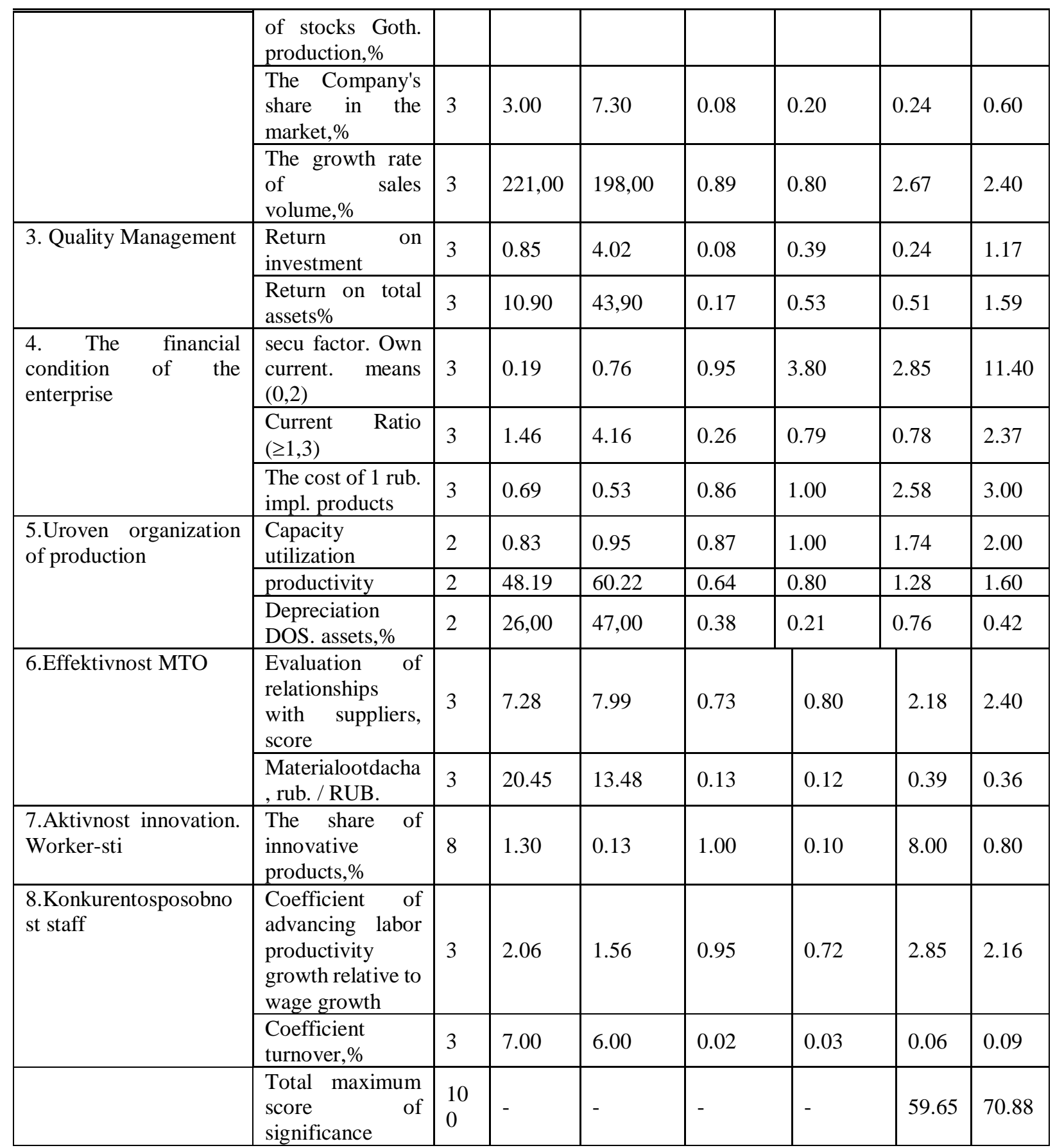

As is evident from Table 2 shown below, the deviation in the potential marketing effectiveness of "Leone" is -7.97, ZAO "Donobuv" -5.4. The greatest influence on this deviation has an indicator of the level and quality of partnerships with stakeholders, so to increase the effectiveness of marketing activities investigated enterprises should establish and develop relationships with partners.

Table 2. Analysis of efficiency of marketing potential

\begin{tabular}{|c|c|c|c|c|c|c|}
\hline \multirow{2}{*}{$\begin{array}{l}\text { Indicators to measure } \\
\text { the effectiveness of } \\
\text { marketing }\end{array}$} & \multirow{2}{*}{ 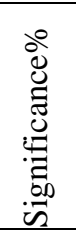 } & \multicolumn{2}{|c|}{$\begin{array}{l}\text { Weighted evaluation of the } \\
\text { competitiveness indicators }\end{array}$} & \multirow{2}{*}{$\begin{array}{l}\text { The maximum } \\
\text { weighted score }\end{array}$} & \multicolumn{2}{|c|}{$\begin{array}{l}\text { Deviation weighted estimation } \\
\text { of the maximum }\end{array}$} \\
\hline & & OOO "Leon" & $\begin{array}{l}\text { CJSC } \\
\text { "Donobuv" }\end{array}$ & & OOO "Leon" & $\begin{array}{l}\text { CJSC } \\
\text { "Donobuv" }\end{array}$ \\
\hline
\end{tabular}




\begin{tabular}{|c|c|c|c|c|c|c|}
\hline \multirow{4}{*}{ Impact Factor: } & ISRA (India) & $=3.117$ & SIS (USA) & $=0.912$ & ICV (Poland) & $=6.630$ \\
\hline & ISI (Dubai, UAI & $=0.829$ & РИНЦ (Russia) & $=0.156$ & PIF (India) & $=1.940$ \\
\hline & GIF (Australia) & $=0.564$ & ESJI (KZ) & $=8.716$ & IBI (India) & $=4.260$ \\
\hline & JIF & $=1.500$ & SJIF (Morocco) & $=5.667$ & OAJI (USA) & $=0.350$ \\
\hline
\end{tabular}

\begin{tabular}{|l|l|l|l|l|l|l|}
\hline $\begin{array}{l}\text { Assessment of the } \\
\text { level of partnership } \\
\text { with the interested } \\
\text { parties of the } \\
\text { enterprise, score }\end{array}$ & 7.1 & 7.6 & 10 & -2.9 & -2.4 \\
\hline $\begin{array}{l}\text { Exceeding the } \\
\text { permissible level of } \\
\text { stocks } \\
\text { production,\% Goth. }\end{array}$ & 3 & 1.02 & 3 & 3 & -1.98 & 0 \\
\hline $\begin{array}{l}\text { The Company's share } \\
\text { in the market, }\end{array}$ & 3 & 0.24 & 0.6 & 3 & -2.76 & -2.4 \\
\hline $\begin{array}{l}\text { The growth rate of } \\
\text { sales volume, } \%\end{array}$ & 3 & 2.67 & 2.4 & 3 & -0.33 & -0.6 \\
\hline in total & 19 & 11.03 & 13.6 & 19 & -7.97 & -5.4 \\
\hline
\end{tabular}

Thus, in assessing the competitiveness of the enterprises investigated revealed that the level of competitiveness of the company "Leon" and CJSC "Donobuv" - average $(59.65 \%$ and $70.88 \%$ respectively). One of the important factors that affect the evaluation of the competitiveness - marketing effectiveness. From the analysis shows that the deviation of this potential is in LLC "Leon" - 7.97, JSC "Donobuv"-5.4. In order to improve the effectiveness of marketing enterprises should introduce the concept of stakeholders, which will contribute to the development of relations with partners.

So, to increase the competitiveness of the investigated companies in partnership theory is proposed to introduce mechanism of interaction with stakeholders.

Thus, the theory of partnership becomes relevant for today, thus taking into account the importance of the factor of the technique of estimation of competitiveness of the enterprise with the new paradigm - the theory of partnership. The developed method of evaluation and analysis of the competitiveness of the enterprise on the basis of the theory of partnerships, allows an in-depth analysis of the competitiveness of enterprises, taking into account an important factor for competitive advantage in a networked economy - the quality and level of development partnerships.

The main unique aspects of competitive advantage based enterprises based on the theory partnerships can be identified:

- the creation and expansion of a permanent database of key partners;

- the formation of the necessary technical resources (computers, peripherals and software);

- organization of activity units and individual managers to manage relationships with stakeholders;

- development and updating of plans for cooperation with key partners in accordance with their business and personal features;
Regular audit of activity of managers to manage relationships with partners in the context of evaluating the following indicators:

- number of meetings with partners, the number of trained commercial proposals, the number of contracts, the speaker volume of deliveries of production attributable to each partner;

- Regular market research in partnership in order to identify changes in the structure and character of preferences when choosing a partner.

Thus, the above-mentioned aspects in the proper level of their study may allow the enterprise to create a unique competitive advantage - the system of relationships with stakeholders, to ensure their competitiveness and the competitiveness of products.

To evaluate the efficiency of the developed innovative processes proposed use efficiency coefficient (Keff), the value of which should be regarded as the coefficient of concordance value for evaluating a priori the outcome of ranking $(\mathrm{W})$, which changes from 0 to 1 . If its value tends to unity, this means that the manufacturer was able to find the most optimal solution innovation process, if its value goes to zero - that requires an analysis of the reasons for this unsatisfactory of total and troubleshooting, provoked obtain such a result, and ways to address past failures [1-2].

The coefficient of efficiency of the process is calculated by the formula:

$\mathrm{Keff}=\mathrm{K} 1 \cdot \mathrm{K} 2 \cdot \mathrm{K} 3 \cdot \mathrm{K} 4 \cdot \mathrm{K} 5 \cdot \mathrm{K} 6 \cdot \mathrm{K} 7 \cdot \mathrm{K} 8 \cdot$

K9 K10 $\cdot \mathrm{K} 11 \cdot \mathrm{K} 12(1)$

wherein Keff - weighting coefficient of efficiency evaluation of technological processes for the production of formed competitive and marketable products

K1 - the weight of labor productivity (PT);

K2 - the weight of the working load (WP);

$\mathrm{K} 3$ - the weight of the shoe release (Ps);

$\mathrm{K} 4$ - the weight of equipment cost per unit of the job flow (C);

K5 - the weight of the total rates per unit of output (Sobsch); 


\begin{tabular}{|c|c|c|c|c|c|c|}
\hline \multirow{4}{*}{ Impact Factor: } & ISRA (India) & $=3.117$ & SIS (USA) & $=0.912$ & ICV (Poland) & $=6.630$ \\
\hline & ISI (Dubai, UAE & $=0.829$ & РИНЦ (Russia & $=0.156$ & PIF (India) & $=1.940$ \\
\hline & GIF (Australia) & $=0.564$ & ESJI (KZ) & $=8.716$ & IBI (India) & $=4.260$ \\
\hline & JIF & $=1.500$ & SJIF (Morocce & $=5.667$ & OAJI (USA) & $=0.350$ \\
\hline
\end{tabular}
(FPC);

K6 - the weight of a stock of financial strength

K7 - the weight of the break-even point (Tb.u);

$\mathrm{K} 8$ - the weight of a unit of production profits (Prov.);

K9 - weight of profitability of products (R);

K10 - the weight of the cost of 1 ruble of marketable products (Z1r.t.p);

K11 - the weight of semi-variable costs (total variable cost of a unit of production) (Zusl.per.ed);

K12 - the weight of fixed costs (total fixed costs per unit of output production) (Zusl.pos.ed).

When calculating estimates of dimensionless efficiency ratio (EFC) by the software there is a need to formulate these same criteria as their evidence. For example, the profit per unit of output depends on the profitability of production, that is, first formulated margins from $5 \%$ to $25 \%$, and then laid the size of a unit of production profits. A similar feature exists with the definition of productivity criterion, because at first use innovative processes, formed on the basis of universal and multi-functional equipment maintenance which should be highly trusted and responsible executives, empathic for the overall result of the entire production cycle, guaranteeing them the production of marketable and competitive products, enjoyed by consumers of domestic markets in high demand. Calculation of fixed costs per unit of production and semi-variable costs per unit of output is interconnected with the peculiarities of the organization of competitive and marketable products, including for children. Performance analysis of the leading foreign manufacturers confirms the fact that, if fixed costs are $20 \%-40 \%$ of the cost of production, then, of course, conditional instance variables costs $60 \%-80 \%$.If this again need to focus on the production of feature products for children, and when profit margins, fixed costs and semi-variable costs are generated based on the implementation of the requirements of technical regulations and normative documents and acts to ensure their safety when using them life. And if this is due to the need to produce them with such stringent performance - the state and the producers have to be interested in each other, and to provide producers compensation for the additional costs of compliance and the assurance that manufactured products do not cause harm to children's health.

Of course, if the criteria for loss of wages per unit of output has to go to zero, and the volume of the shoe with a $1 \mathrm{~m} 2$ - to its maximum possible value, and the cost of 1 commodity products ruble shall endeavor to achieve the minimum possible value and the cost of equipment per unit of flow setting also aspire to the minimum possible value and other criteria - to their maximum possible value - together dimensionless performance evaluation developed innovative technological processes (EFC) must always three to one. Thereby affirm that designed an innovative process for the production of the company they import-substituting products will be successful in their work for the benefit of the population of the regions where it will operate,

Thus, the authors developed software to assess the effectiveness of the generated innovative technological processes for the production of footwear import-substituting range of calculation taking into account the calculated components for the manufacture of the planned range allows us to take justified decision on its launch. And also make a decision about his balance, guaranteed demand for manufactured products and ensure sustainability of the enterprise's financial position, are shown in Table 1 .

Also, the authors of the software to select the optimum capacity has been developed, the calculation results are shown in Table 1.

Table 1 - Calculation of technical and economic parameters at the optimum power with a range of 300-900 pairs in the production of men's shoes / women's shoes

\begin{tabular}{|l|l|l|l|l|l|ll|}
\hline Power* & $\begin{array}{l}\text { Equipment } \\
\text { Type * }\end{array}$ & $\begin{array}{l}\text { optimal } \\
\text { power, } \\
\text { steam, in a } \\
\text { shift }\end{array}$ & $\begin{array}{l}\text { productivity } \\
1 \text { telnost labor } \\
\text { worker pairs }\end{array}$ & $\begin{array}{l}\text { The } \\
\text { percentage of } \\
\text { the working } \\
\text { load,\% }\end{array}$ & $\begin{array}{l}\text { Loss of wages } \\
\text { per uni of } \\
\text { output, rubles }\end{array}$ & $\begin{array}{l}\text { Average } \\
\text { expenses for } \\
100 \text { pairs of } \\
\text { shoes, rub }\end{array}$ \\
\hline $300-500$ & 1 & $500 / 500$ & $28.09 / 27.73$ & $61.39 / 62.18$ & $13.68 / 13.4$ & $\begin{array}{l}6735.36 \\
6980.5\end{array}$ \\
\hline $500-700$ & 1 & $556 / 700$ & $27.73 / 27.73$ & $69.14 / 69.14$ & $9.83 / 9.83$ & $\begin{array}{l}6404.71 \\
6277.43\end{array}$ \\
\hline $700-900$ & 1 & $889 / 847$ & $28.09 / 27.73$ & $77.20 / 74.5$ & $6.42 / 7.54$ & $\begin{array}{l}5236.17 \\
6277.43\end{array}$ \\
\hline $300-500$ & 2 & $500 / 500$ & $28.09 / 24.45$ & $61.39 / 63.9$ & $13.68 / 14.01$ & $\begin{array}{l}6728.68 \\
7630.92\end{array}$ \\
\hline
\end{tabular}




\begin{tabular}{|c|c|c|c|c|c|c|}
\hline \multirow{4}{*}{ Impact Factor: } & ISRA (India) & $=3.117$ & SIS (USA) & $=0.912$ & ICV (Poland) & $=6.630$ \\
\hline & ISI (Dubai, UAE & $=0.829$ & РИНЦ (Russia & $=0.156$ & PIF (India) & $=1.940$ \\
\hline & GIF (Australia) & $=0.564$ & ESJI (KZ) & $=8.716$ & IBI (India) & $=4.260$ \\
\hline & JIF & $=1.500$ & SJIF (Morocce & $=5.667$ & OAJI (USA) & $=0.350$ \\
\hline
\end{tabular}

\begin{tabular}{|l|l|l|l|l|l|ll|}
\hline $500-700$ & 2 & $556 / 556$ & $27.91 / 27.73$ & $68.70 / 69.14$ & $9.97 / 9.83$ & 6083.28 & $/$ \\
& & & & & & 6404.71 & \\
\hline $700-900$ & 2 & $889 / 812$ & $28.09 / 25.64$ & $77.20 / 75.4$ & $6.42 / 7.77$ & 5240.72 & $/$ \\
& & & & & & 6060.55 & \\
\hline $300-500$ & 3 & $500 / 500$ & $28.09 / 27.0$ & $61.39 / 61.74$ & $13.68 / 14.02$ & 7533.95 & $/$ \\
& & & & & & 7827.12 & \\
\hline $500-700$ & 3 & $700 / 556$ & $28.12 / 29.32$ & $67.28 / 68.21$ & $10.56 / 9.71$ & 6734.02 & $/$ \\
& & & & & & 6607.65 & \\
\hline $700-900$ & 3 & $889 / 847$ & $28.09 / 27.0$ & $77.20 / 74.7$ & $6.42 / 7.66$ & 5876.59 & $/$ \\
& & & & & & 6341.05 & \\
\hline
\end{tabular}

* - options for power, and similar types of equipment

Table 1 shows the calculations for the optimum power range from 300 to 900 pairs of men's and women's shoes entire assortment of footwear. Analysis of the obtained characteristics for three selections predetermined process in the manufacture of the entire assortment of shoes confirmed the effectiveness of the software product, below, to assess the proposed innovative process using a universal and multi-functional equipment. Thus, when the range of between 300 - 900 pairs of well defined criteria is the volume of 889 pairs of men's shoes and 847 pairs of women's shoes.

At the same time, as the criteria for informed choice of an optimum power in the formation of the algorithm is justified were chosen precisely those criteria that have the greatest impact on the cost of the finished product [4]:

- loss of wages per unit of output, rub .;

- release shoe $1 \mathrm{~m} 2$;

- load percentage of workers, $\%$;

- productivity per worker pair;

- given the specific costs of 100 pairs of shoes, rub ;

- equipment cost per unit job flow (C)

- total rate (Sobsch);

- financial strength (FPC);

- break-even point (Tb.u);

- profit per unit of output (Prov.);

- Return products ( $\mathrm{R})$;

- the cost of 1 rub. commodity products (Z1r etc.);

- semi-variable costs (Zusl per.ed..);

- conventionally fixed costs (Zusl. pos.ed).

From these criteria, in our opinion, the manufacturer is able to give preference to those from his point of view, it would guarantee the production of import-substituting, competitive and marketable products, namely:

- Labor 1 worker productivity - a key indicator of labor. The level and dynamics of labor productivity depend to a greater or lesser extent all the key performance indicators of production and all the labor indicators: production, employment, consumption wages, wages. of paramount importance for improving productivity are the introduction of new technology, extensive mechanization of labor- intensive work, the automation of production processes, training of staff and workers, especially in the implementation of innovative technological processes on the basis of universal and multifunctional equipment;

- given the specific costs - an indicator of comparative economic efficiency of capital investments used in selecting the best of the solutions to technological problems;

- reduced costs - the amount of current costs accounted in the cost of production and non-recurring capital investments, comparability with current costs which is achieved by multiplying them by a regulatory factor capital efficiency;

- financial strength (ZFP) shows how many percent of the company can reduce the sales volume without incurring losses;

- break-even point allows (Tb.u) to determine the minimum required volume of product sales, in which the company covers its costs and break even works without giving profit, but also does not suffer losses, that is a minimum output size that income equality is achieved from sales and costs of production;

- Profit (loss) from sale of goods (PR) is defined as the difference between revenue from sales in current prices, VAT and excise taxes and the cost of its production and sales;

- the profitability of the product $(\mathrm{R})$ represents the relationship between the profit from the sale of units of production and its cost;

- fixed costs (total fixed costs per unit of output production) (Zusl.pos.ed) that vary in proportion or almost proportion to the volume of production (1st Class - cost of raw materials and materials; 2 st - costs of auxiliary materials; $3 \mathrm{st}$ - costs fuel and energy for technological needs; 4st - costs and additional basic wage of production workers with insurance premiums to non-budgetary funds);

- semi-variable costs (total variable cost of a unit of production) (Zusl per.ed..), Which are independent or nearly independent of changes in the volume of production (5CT - costs for the preparation and development costs of production; Article 6 - costs the cost of maintaining and operating the equipment; $7 \mathrm{st}$ the cost of overhead needs; 8st - costs for general expenses, they, along with fixed costs make up the production cost; Article 9 - on business expenses costs 


\begin{tabular}{|c|c|c|c|c|c|c|}
\hline \multirow{4}{*}{ Impact Factor: } & ISRA (India) & $=3.117$ & SIS (USA) & $=0.912$ & ICV (Poland) & $=6.630$ \\
\hline & ISI (Dubai, UAE & $=0.829$ & РИНЦ (Russia & $=0.156$ & PIF (India) & $=1.940$ \\
\hline & GIF (Australia) & $=0.564$ & ESJI (KZ) & $=8.716$ & IBI (India) & $=4.260$ \\
\hline & JIF & $=1.500$ & SJIF (Morocce & $=5.667$ & OAJI (USA) & $=0.350$ \\
\hline
\end{tabular}

all of these articles. and - forming a semi-variable costs and fixed costs make up the full cost, ie semivariable costs are defined as total cost minus fixed costs, and vice versa,

- the cost of 1 rub. commodity production show the relative size of profit on each ruble of current expenditure, ie the ratio of unit cost to the wholesale price, which characterizes the efficiency of carried out measures to improve the competitiveness of and demand for products in the supply markets [4].

Characteristics of competitive advantages in the production of the whole assortment of shoes for a decision on its manufacture, which is calculated using the same software product are shown in Table 2.

Table 2 - components of the calculation for the entire product range of footwear.

\begin{tabular}{|c|c|c|c|c|c|}
\hline \multirow[b]{2}{*}{ Indicators } & \multirow[b]{2}{*}{ Rod shoes } & \multicolumn{4}{|c|}{ types of shoes } \\
\hline & & Spring & Summer & Autumn & Winter \\
\hline \multirow{3}{*}{ Unit costs, rubles. } & Men's & 856.77 & 643.72 & 998.5 & 1007.07 \\
\hline & Women's & 933.51 & 844.31 & 1062.37 & 2107.29 \\
\hline & nursery & 551.05 & 503.89 & 586.15 & $\begin{array}{l}795.4 \\
\text { one }\end{array}$ \\
\hline \multirow{3}{*}{ The cost of basic materials, rub. } & Men's & 541.61 & 378.64 & 623.16 & 660.42 \\
\hline & Women's & 523.71 & 511.6 & 618.52 & 1503.57 \\
\hline & nursery & 235.78 & 200.05 & 280.76 & 415.5 \\
\hline \multirow{3}{*}{$\begin{array}{l}\text { The costs of auxiliary materials, } \\
\text { rub. }\end{array}$} & Men's & 23.82 & 17.57 & 28,16 & 30.4 \\
\hline & Women's & 22.65 & 17,05 & 24.31 & 43,16 \\
\hline & nursery & 11.78 & 7.92 & 12.16 & 15.26 \\
\hline \multirow{3}{*}{$\begin{array}{l}\text { wages } \\
\text { pay }\end{array}$} & Men's & 141.02 & 108.28 & 161.1 & 150.71 \\
\hline & Women's & 148.92 & 84.62 & 139.09 & 220.58 \\
\hline & nursery & 58.44 & 55.42 & 68.95 & 95.77 \\
\hline \multirow{3}{*}{$\begin{array}{l}\text { profitability of production units, } \\
\text { rub. }\end{array}$} & Men's & 10.75 & 14.65 & 13.36 & 15.12 \\
\hline & Women's & 11.88 & 13.37 & 16.42 & 17,11 \\
\hline & nursery & 9.53 & 8.39 & 9.19 & 10.72 \\
\hline \multirow{3}{*}{$\begin{array}{l}\text { Zatratyna } 1 \text { rub. } \\
\text { marketable products, rub. }\end{array}$} & Men's & 82.88 & 85.35 & 86.64 & 84.88 \\
\hline & Women's & 88,12 & 86.63 & 83.57 & 82.89 \\
\hline & nursery & 90.47 & 91.62 & 90.8 & 89.28 \\
\hline
\end{tabular}

Thus, the author developed software to assess the effectiveness formed of innovative technological processes for the production of import-substituting range of footwear based on the calculated of calculation components for the manufacture of the planned range allows us to take justified decision on its launch, the decision on its balance, guaranteed demand and ensuring the company a stable financial position.

In addition, the software allows the regional and municipal branches of government, together with the future manufacturers around the assortment of shoes in mono generate volumes of footwear is not only based on its needs, but also to ensure stability of the enterprise's financial condition by providing them stable TEP, that is to be created the basis for the creation of new jobs at the same time the solution to all social problems, with regret, today characterized by the majority of small and medium-sized m Russian cities.

It can be divided into a partnership into two groups: external and internal. The external include: customers, suppliers, competitors, government agencies and organizations, regional governments, financial intermediaries.

Buyers. Strategy and tactics of work with important customers include joint meetings to determine the driving forces behind business change, mutual efforts on the development of products and markets, increased communication links, the use of common areas and joint training programs and services. Strengthening ties with customers often provides significant benefits [1]. 


\begin{tabular}{|c|c|c|c|c|c|c|}
\hline \multirow{4}{*}{ Impact Factor: } & ISRA (India) & $=3.117$ & SIS (USA) & $=0.912$ & ICV (Poland) & $=6.630$ \\
\hline & ISI (Dubai, UAE & $=0.829$ & РИНЦ (Russia & $=0.156$ & PIF (India) & $=1.940$ \\
\hline & GIF (Australia) & $=0.564$ & ESJI (KZ) & $=8.716$ & IBI (India) & $=4.260$ \\
\hline & JIF & $=1.500$ & SJIF (Morocce & $=5.667$ & OAJI (USA) & $=0.350$ \\
\hline
\end{tabular}

Internal stakeholders include managers, employees, owners and the board of directors or board of directors, which represents managers and owners. One of the most significant domestic partners - the CEO.

Thus, the success of the organization is determined by the degree of satisfaction of interests of stakeholders, so to enhance the competitiveness and performance, the company must take into account not only its own interests but also the interests of stakeholders. Therefore, taking into account the consideration of the methodological foundations of competitiveness of the enterprise, the methods of estimating and analyzing the competitiveness of the enterprise on the basis of stakeholder theory. [2] Step 1. Selection indicators for assessing competitive factors businesses. For each factor can be determined system of indicators based on analysis of the scientific literature (Table 1).So, taking into account the analysis of the system of indicators to measure the competitive potential of the company, we can offer the following system of indicators to measure the competitiveness of domestic factors enterprise (Table 2).Step 2: Determination of the importance of indicators in assessing the overall competitiveness.

Table 1. The system of indicators for assessing the competitive potential Shoe companies

\begin{tabular}{|c|c|}
\hline The factors of competitive potential & evaluation indicators \\
\hline 1 & 2 \\
\hline \multirow{6}{*}{ marketing 1.Effektivnost } & quality ratio of the product and its cost of production and marketing \\
\hline & The pace of growth of marketable products \\
\hline & The growth in sales and profits \\
\hline & Profitability \\
\hline & Market share, image \\
\hline & Quality partnerships \\
\hline 2. Quality Management & $\begin{array}{l}\text { The yield on total assets, return on equity; investment rate of return } \\
\text { Net profit per } 1 \text { ruble. sales volumes; sales profit per } 1 \text { ruble. sales } \\
\text { volumes; otch profit. Period of } 1 \text { ruble. the volume of sales }\end{array}$ \\
\hline 3.Finansovoe state enterprises & $\begin{array}{l}\text { Coefficient of own means; current ratio; coverage ratio, equity ratio, } \\
\text { an index of permanent capital, the overall profitability of the company, } \\
\text { return on equity, return on products }\end{array}$ \\
\hline $\begin{array}{l}\text { 4. The level of organization of } \\
\text { production }\end{array}$ & $\begin{array}{l}\text { Capacity utilization; production and marketing capacity; the volume } \\
\text { and direction of capital } \\
\text { The share of certified products in accordance with international } \\
\text { standards ISO } 9000 \\
\text { Wear OPF, productivity growth }\end{array}$ \\
\hline 5. The effectiveness of MTO & $\begin{array}{l}\text { Quality and price of supplied materials. Materialootdacha, turnover, } \\
\text { allowing direct connections; Incoming goods uniformity coefficient; } \\
\text { the profitability of the transaction costs; the profitability of the product } \\
\text { purchase }\end{array}$ \\
\hline 6. The activity of innovation & $\begin{array}{l}\text { The annual cost for research and development, the number of patents } \\
\text { The share of innovative products, the share of exports, the number of } \\
\text { created advanced technologies } \\
\text { The volume of shipped innovative products (services), the number of } \\
\text { patented technologies, the number of technologies with patent purity, } \\
\text { innovation expenditure, the number of acquired and transmitted by new } \\
\text { technologies, software, }\end{array}$ \\
\hline 7.Konkurentosposobnost staff & $\begin{array}{l}\text { The coefficient of turnover, the ratio of an advancing labor productivity } \\
\text { relative to wages, educational level of the labor force, the level of } \\
\text { professional skills of workers }\end{array}$ \\
\hline
\end{tabular}

The significance of evaluation indices of each factor competitive potential is shown in Table 2. 


\begin{tabular}{|c|c|c|c|c|c|c|}
\hline \multirow{4}{*}{ Impact Factor: } & ISRA (India) & $=3.117$ & SIS (USA) & $=0.912$ & ICV (Poland) & $=6.630$ \\
\hline & ISI (Dubai, UAE & $=0.829$ & РИНЦ (Russia & $=0.156$ & PIF (India) & $=1.940$ \\
\hline & GIF (Australia) & $=0.564$ & ESJI (KZ) & $=8.716$ & IBI (India) & $=4.260$ \\
\hline & JIF & $=1.500$ & SJIF (Morocce & $=5.667$ & OAJI (USA) & $=0.350$ \\
\hline
\end{tabular}

Table 2. Recommended scorecard enterprise competitiveness assessment and their importance

\begin{tabular}{|c|c|c|}
\hline $\begin{array}{l}\text { Factors of competitiveness of } \\
\text { the enterprise }\end{array}$ & Indicators & Significance $\%$ \\
\hline 1.Konkurentospo-lities goods & The weighted average Product Line competitive goods & 40 \\
\hline \multirow[t]{5}{*}{ marketing 2.Effektivnost } & Exceeding the permissible level of stocks of finished goods & 3 \\
\hline & The share of the enterprise market & 3 \\
\hline & The growth rate of sales volume & 3 \\
\hline & $\begin{array}{l}\text { Assessment of the level of partnership with interested parties } \\
\text { the enterprise }\end{array}$ & 10 \\
\hline & in total & 19 \\
\hline \multirow[t]{3}{*}{ 3. Quality Management } & Return on investment & 3 \\
\hline & Return on total assets & 3 \\
\hline & in total & 6 \\
\hline \multirow{4}{*}{$\begin{array}{l}\text { 4. The financial condition of the } \\
\text { enterprise }\end{array}$} & The coefficient of its own working capital & 3 \\
\hline & Current ratio & 3 \\
\hline & The cost of 1 rub. of sales & 3 \\
\hline & in total & 9 \\
\hline \multirow{4}{*}{$\begin{array}{lll}\text { 5.Uroven } & \text { organization } \\
\text { production }\end{array}$} & Capacity utilization & 2 \\
\hline & productivity & 2 \\
\hline & Depreciation & 2 \\
\hline & in total & 6 \\
\hline \multirow[t]{3}{*}{ 6. The effectiveness of MTO } & Reduction of material level & 3 \\
\hline & Materialootdacha & 3 \\
\hline & in total & 6 \\
\hline \multirow[t]{3}{*}{ 7. The activity of innovation } & The share of innovative products & 4 \\
\hline & Expenditure on innovation & 4 \\
\hline & in total & 8 \\
\hline \multirow[t]{5}{*}{ 8.Konkurentosposobnost staff } & $\begin{array}{l}\text { Coefficient of advancing labor productivity growth relative to } \\
\text { wage growth }\end{array}$ & 3 \\
\hline & Coefficient turnover & 3 \\
\hline & in total & 6 \\
\hline & Total significance of the competitive potential & 60 \\
\hline & Total maximum score of significance & 100 \\
\hline
\end{tabular}

Step 3: Calculate the dimensionless ratings performance of the enterprise competitiveness.

To translate dimension indicators assessments are encouraged to use the dimensionless index method. Indices dimensionless parameters determined by the formula (1) for the positive indicators with a positive trend - the growth (eg, return on sales, productivity) and the formula (2) for negative indicators with a positive trend - the decline (eg, depreciation, excess inventory of finished products in stock compared with the norm, the turnover rate), taken mainly of the indicators that form the production cost [3-4]:

$$
\begin{aligned}
& O_{i}=X_{i} / X_{i}^{\max } \\
& O_{i}=X_{i}^{\min } / X_{i} .
\end{aligned}
$$

where Oi - dimensionless (index) score of i-index of competitiveness of the enterprise,

$x i$ - the value of the i-th dimension index evaluation of enterprise competitiveness,

Himax - the maximum value of i-dimensional index evaluation of enterprise competitiveness,

Himin- the minimum value of i-dimensional index evaluation of enterprise competitiveness.

Step 4: Estimation of competitiveness of the goods. It carried out for light industry products in their domestic demand [5-6].

Step 5. Calculation of summary measure the competitiveness of enterprises. Quantitative assessment of the competitiveness of enterprises is proposed to determine the formula (3):

$$
K_{\Pi}=\sum_{i=1}^{m} \alpha_{i} \times O_{i}
$$




\begin{tabular}{|c|c|c|c|c|c|c|}
\hline \multirow{4}{*}{ Impact Factor: } & ISRA (India) & $=3.117$ & SIS (USA) & $=0.912$ & ICV (Poland) & $=6.630$ \\
\hline & ISI (Dubai, UAI & $=0.829$ & РИНЦ (Russia & $=0.156$ & PIF (India) & $=1.940$ \\
\hline & GIF (Australia) & $=0.564$ & ESJI (KZ) & $=8.716$ & IBI (India) & $=4.260$ \\
\hline & JIF & $=1.500$ & SJIF (Morocco & $=5.667$ & OAJI (USA) & $=0.350$ \\
\hline
\end{tabular}

where KP - an estimation of competitiveness of the enterprise as a percentage,

$\alpha_{i}$ - the importance of the i-th index of competitiveness as a percentage,

$O i$ - index (dimensionless) evaluation of i-index of competitiveness,

$m$ - the number of indicators of competitiveness of the enterprise valuation.

Evaluation value competitiveness of the enterprise can theoretically range from 0 to 100 (ratio 4) [7].

$$
K n=0 \div 100 \text { (four) }
$$

For qualitative characteristics of the obtained competitive assessment scale required quality level evaluation. In economic practice, a principle of the scales at regular intervals, progressive and regressive scale. Progressive and regressive scale is most often used for material incentives. We believe that is the most appropriate scale with equal pitch, because it firstly corresponds to the solution of practical problems (qualitative specification competitiveness), secondly, the construction and easy to use. Step scale is defined as a 100 (maximum score): 4 (number of levels) $=25$. You can select and other step values that defined goals and objectives, which currently generates the enterprise itself.

Considering the traditional technological processes for the production of leather products, which are now a source of negative effects on the environment and human health, it can be said that almost each of the process steps in one degree or another is environmentally dangerous. Problems of maintenance of industrial safety and health of consumers, and today remains an urgent and requires the involvement of as highly qualified and competent experts.

If Customs Committee (TC) is necessary to ensure the professional competence of the experts, it is necessary to use developed by the authors in addition to the program for processing a priori ranking results, expanding its capabilities by giving it a merit function. This need has arisen due to a substantial increase in customs operations. Now customs have to be invited as experts broader and not always prepared by a group of experts to participate in the quality assessment of such a wide range of products without sufficient experience to have qualified assessment of the full range of goods at the customs office, which could trigger supply of the domestic market of substandard products.

It is necessary to warn the heads of the organizations, which attract experts of their obligations to ensure concise, unambiguous information about the products in which the decoding and will involve experts engaged by them. The advantages of this information is succinct, unambiguous, but the perception of characters requires some training to decrypt the information. Basic requirements for a commodity include the following: availability, adequacy, reliability.

These requirements were called as "Three A" [1].

- The first "D" - reliability - requires truthfulness and objectivity of the information about the product, the absence of deception. The unreliability of the information is the information falsification.

- The second "D" - accessibility - related to the principle of information openness of information about the product for all users. The Federal Law "On Protection of Consumers' Rights states that the product information should be in Russian.

- the third "D" - sufficiency - treated as rational information richness, i.e. It should be excluded as incomplete and redundant information. Incomplete information, for example, not specified shelf life of dairy products, can lead to damage caused to health of the consumer. The excess of information - it is useless information about the product, they can cause irritation and encourage consumers to abandon the purchase. Realizing the importance to society as experts-experts involved TC TC for customs expertise to provide customers with high quality products, guaranteeing their security and protect them from the use of substandard products, the authors proposed a new method for assessing the competence of professionals involved TC for their participation in the Customs examination. Filling processes for the production of competitive and popular footwear for consumers SFD and North Caucasus Federal District regions is costly. Using the universal and multifunctional equipment generates a workflow in a way that allows to make the whole product range of high quality shoes and with different price niche.

But in this case it is necessary to find a solution that would allow the manufacturer to have a tool to assess the effectiveness of innovation processes. Such a solution is possible if the in each case be used to assess the effectiveness of such a coefficient, whose value as a coefficient of concordance (W), will vary from $\mathrm{O}$ to 1 . If the value $(\mathrm{W})$ approaches unity, it means that the manufacturer has find the best solution, if the value (W) tends to zero - that requires an analysis of the reasons for this unsatisfactory outcome and troubleshooting, provoked obtain such a result [1$3]$.

In practice, expert estimation was extended competence assessment with the help of expert self. [2] There are different approaches to the assessment of this indicator. In accordance with a methodology for assessing the competence of expert auditors is based on the calculation of the coefficient of competence $\mathrm{Kj}$, which is calculated on the basis of expert judgment of the auditor on the degree of awareness of the problem at hand and specify the 


\begin{tabular}{|c|c|c|c|c|c|c|}
\hline \multirow{4}{*}{ Impact Factor: } & ISRA (India) & $=3.117$ & SIS (USA) & $=0.912$ & ICV (Poland) & $=6.630$ \\
\hline & ISI (Dubai, UAI & $=0.829$ & РИНЦ (Russia & $=0.156$ & PIF (India) & $=1.940$ \\
\hline & GIF (Australia) & $=0.564$ & ESJI (KZ) & $=8.716$ & IBI (India) & $=4.260$ \\
\hline & JIF & $=1.500$ & SJIF (Morocco & $=5.667$ & OAJI (USA) & $=0.350$ \\
\hline
\end{tabular}

argument of opinion sources. Competence factor, $\mathrm{Kj}$, is calculated by the formula:

$$
\mathrm{Kj}=1 / 2(\mathrm{Kuj}+\mathrm{Kaj}) \text {, }
$$

where in Kuj - coefficient on the problem of awareness; Kaj - reasoning factor for the same problem. expert knowledge ratio is calculated on the basis of self-esteem expert, namely:

- awareness of the state of the modern market economy;

- awareness in the state of affairs in light industry;

- competence in the field of marketing communications;

- competence in marketing communications.

The numerator of the expert auditor puts down the self-assessment score (from 1 to 10), with the maximum score (10) corresponds to an acquaintance on the authorship of the level (collaboration) to develop specific approaches to solving the proposed problems for him, the minimum score (1) - complete lack of familiarity with the considered problem. After completing the self-assessment by experts-auditors being adjusted scoring, ie obtained value is multiplied by a factor of 0.1 and entered into the denominator. Thus, the transfer points is carried in a range of values from 0 to 1 , which is most common for the calculation of the coefficient of their competence.

argument ratio is determined by summing up evaluation scores argumentation, namely: High - 1, average $0.8 \quad 0.5$ Low. Thus the criterion for "Theoretical analysis expert evaluation argumentation" $\quad(0.3$ to 0.1$)$, "Manufacturing experience expert" ( 0.5 to 0.2$)$, and the criteria for "evaluation results generalized work of Russian authors" "The results of evaluation of foreign authors generalized the works."

Expert competence assessment method with their participation in the work of expert committees of various organizations can be used if there is a reasonable argument on the reliability of the results of their work. If there is a need in the head of the organization, which forms the expert commission in a personal assessment of the competence of each participant, in this case, we propose to use a new method, the essence of which involves a personalized assessment of the competence of each expert with the developed software product. One of the conditions of competitiveness of the enterprise - the organization of effective interaction with stakeholders in the successful functioning of the enterprise parties. Each company, even in small groups, there are several subjects with different interests, with which it can be temporary or permanent cooperation. To studying these interests, ways of solving problems between external and internal parties, the establishment of relations between the partners, dedicated to the study authors, to ensure that all parties interested in the implementation of the main principles - all interests are legitimate and require them to meet and respect. [4]

The nature of the new competition in today's global economy, caused by globalization, poses high demands on manufacturers increase the competitiveness of goods and enterprises. Improving the competitiveness of enterprises and industries is one of the most important areas of real economic growth, both in Russia and in the regions of the Southern Federal District and the North Caucasus Federal District, which is reflected in the policy document, namely in the strategy development of light industry of Russia till 2025.

In this context, the problem of competitiveness of the domestic footwear requires the development of the conceptual foundations of theoretical, methodological and practical recommendations, adequate upcoming changes in the organizational economic mechanism of functioning of the country's industrial complex.

Especially urgent task of improving the competitiveness of footwear enterprises which, because of external factors (increased competition due to globalization, the global financial crisis) and internal (ineffective management) lost their competitive position in the domestic and foreign markets. In response to negative processes of regionalization processes are amplified in the external environment and create different network structures, one of which is an alliance of producers and the state.

There are three main options for the enterprise concept in a developed economy: neoclassical, agent (shareholder) and the concept of partnership. The concept of partnership or stakeholder theory, is considered dependent activities of the enterprise from the interests of a wide variety of stakeholders, which include customers, suppliers, shareholders, managers, workers, and others. In addition, each of the partners has a certain right to control over the enterprise, so the concept implies the need to take decisions based on their interests.

Theory of strategic management is one of the most difficult sections of management science. Over a relatively short period of existence, was characterized by the rapid development of a number of concepts, it has succeeded in becoming an independent scientific discipline with its own academic infrastructure. The most important question that must be answered theory is to determine the sources of long-term competitiveness of enterprises. These sources are defined by the Company's strategy and, therefore, raise the question of its nature.

Enterprise System concept may be considered as a starting point for describing the strategic business nowadays, since none of the above concepts "in its pure form does not represent circuitry for analysis of the relevant actual position and the role of the enterprise in any economy." 


\begin{tabular}{|c|c|c|c|c|c|c|}
\hline \multirow{4}{*}{ Impact Factor: } & ISRA (India) & $=3.117$ & SIS (USA) & $=0.912$ & ICV (Poland) & $=6.630$ \\
\hline & ISI (Dubai, UAI & $=0.829$ & РИНЦ (Russia & $=0.156$ & PIF (India) & $=1.940$ \\
\hline & GIF (Australia) & $=0.564$ & ESJI (KZ) & $=8.716$ & IBI (India) & $=4.260$ \\
\hline & JIF & $=1.500$ & SJIF (Morocco & $=5.667$ & OAJI (USA) & $=0.350$ \\
\hline
\end{tabular}

Thus, the authors were able to on the one hand to show the possibilities of examination to assess competency attracted customs specialists for marketing communications for compliance with product regulatory requirements within the $\mathrm{CU} C \mathrm{C}$ and other organizations and the selection preferences in advertising to promote product sales, on the other hand make - competent whether attracted expertauditors or not to allow the leadership of the CC CU and other organizations to reduce errors in their work to attract as well expert - Ditore to work at the office, and consumers will be assured that purchase products of high quality and meets the requirements of technical regulations, standards, codes of conduct or terms of contracts [1-2]. In any case, from all of this it will benefit only the case itself, ie

Transition to independent standardization specifications actually possible within the limits of the objective quality parameters only under two conditions: production;

development of modern technologies of

- the current high professional culture, the backbone of which factor is the personal form of justice.

Of course, to the basic conditions necessary to add non-state control over the production, a kind of people's control. ONF may be the center of this national supervision, but there is a danger of the party registration. The real strength of the ONF just lies in the status of an independent organization of the interparty relations, reporting directly to the President. Higher administrative management, unfortunately, gained experience of taming those who show independence. [1]

In the USSR in the 50 - 80 years it has formed a quality management system, not only what is inferior to foreign experience. This system has been continuously improved, taking into account the resulting positive and negative experiences until the late 1980s. Everything was collapsing in the waves, the birth of "new political thinking". Finally, the system policy for quality management organization overwhelmed nineties democratic tsunami. The crisis and the "shock therapy" was removed urgency of the problem for decades. Reasons deactualization interest to quality lie in plain sight:

- achievements of the Soviet period, the quality management policies have been associated with the peculiarities of socialist-type planning, built on the guiding principles, which, in contrast to the indicative planning, economic incentives has been subordinated to political goals directly. When it became unnecessary administrative command practice business management, along with it went into the history and practice of quality management [2];

- it is no secret that with the collapse of the Soviet Union on Russia's future looked very different "systemic". Russian economy did not try to integrate into global production, and attach to the interests of the existing architecture. We were given a place of manufacturers and suppliers of raw materials, mainly natural origin. The quality of these products is not due to the production. The quality of the production depends on the size of the added value - less costs, the greater the difference between price and cost, higher profits;

- the quality of production and the production of the product is functionally linked to the quality of the market, the quality of the market, in turn, depends on consumer willingness to purchase products marked with quality sign.

The manufacturer is currently not interested to produce a quality product. "Sheepskin is not worth" costs are high, the cost of products will grow, the real price substantially increase the intermediary and the seller. As a result, the market of such a product "can not digest" and the producer will be struck by a deadly disease №1 by W. Edwards Deming. In limited obviously meager for Russian quality items guaranteed to make a scale, made only to do with the situation in the present production practice is not exclusive it.

BS Aleshin - a renowned expert in the field of management, occupied the highest positions in the Russian government and business he knows the inside. He should be familiar with the history of the problem of training managers, leaving the roots in the Soviet period. She tried to solve AG Aghanbegyan when he was director of the Institute of Siberian Branch of the USSR in the system. He did this very seriously, initiated the establishment of the Board of Directors of the largest enterprises in Siberia. Externally, the question seemed simple: economistmanager (then overseas "manager" is not used) is a "free artist", or training necessary to build as an addon production-oriented foundation, ie first careeroriented training, only then economic education. The formal solution to the problem had to departmental universities,

One of the basic rules of quality management experts believe a return to the original position if the process has not gone. Therefore, the restoration of the previous model of economic growth we need to write in the active power. To this I would have to apply the principle of consistency in the implementation of socialist imperative of the unity of theory and practice. Vippersony Soviet Politburo decisions are not developed. They agree upon and adopt them. Draft decisions prepared by professionals, consultants, "subcontractors" and "initiators", they were scientists, Academy of Sciences of the USSR and most successful production managers. Casual man in the industrial departments Regional Party Committee of the CPSU there could only once Stirlitz. It was arranged party and people's control. Certainly not perfect, but effective. Decomposition started when the arrival of M. Gorbachev announced his proteges 


\begin{tabular}{|c|c|c|c|c|c|c|}
\hline \multirow{4}{*}{ Impact Factor: } & ISRA (India) & $=3.117$ & SIS (USA) & $=0.912$ & ICV (Poland) & $=6.630$ \\
\hline & ISI (Dubai, UAI & $=0.829$ & РИНЦ (Russia & $=0.156$ & PIF (India) & $=1.940$ \\
\hline & GIF (Australia) & $=0.564$ & ESJI (KZ) & $=8.716$ & IBI (India) & $=4.260$ \\
\hline & JIF & $=1.500$ & SJIF (Morocco & $=5.667$ & OAJI (USA) & $=0.350$ \\
\hline
\end{tabular}

themselves and scientists, and skilled production workers, and the prophets, losing critical capacity. euphoria muddied mind. Dialectics in the management gave way to a desire to find an existing example that gave rise to rebirth of dialectical thought, built on the basis of historical specificity of true knowledge, in primitive eclecticism Gaidar and $\mathrm{K}^{\circ}$ [3].

The criterion level domain-specific knowledge is the quality of management corresponding region of the objective reality.

There are three "golden truth" quality policy in quality management:

- ignorance - the root cause of all the troubles in the management of the economy in the first place;

- quality - a source of income, as associated with the reduction of production losses, in addition, it ensures economic stability, improves the image;

- gentle policy towards professionally trained personnel, these people - the main wealth of any production.

Rules apply when there is no reason not to comply with them - a more expensive each violation. We have, in terms of selective control over the rules, follow the rules of the rare manufacturers, a significantly greater effect on the concepts, that is, under the guise of imperfection rules and arrangements with officials. And here we can formulate the essence of the political moment, as leaders liked to say not very long ago. So, what do we have?

The first, quite by chance economics uncoupled from politics, political economy was neutralized in economics. God - gods, Caesar - Caesar's. Very much like the oligarchs and Gaidar American economic liberalism, and they repelled him specifically. Free enterprise took "a great success", and the Americans with draconian measures for violation of the rules of economic activity have forgotten to tell people. It was not profitable. Remember were only after all shared, and the question arose about the privatization redistribution of products.

"Quality" - a philosophical category, which together with the "amount" constitutes a dialectical pair, that is, they are interdependent. In one of its publications, we have identified three fundamental trait of "quality":

- "Quality" is a system of determining the properties of the phenomenon;

- in the definition of "quality" always be implied in a number of its manifestations - integrity, intensity;

- reflecting substantive diversity of the world, quality plays a different objective phenomena, it is structured.

"Quality Management" - the notion of political economy, it allows for variability in design, but within objective quality characteristics. Manipulation of quality represents free from the actual determination of quality characteristics signs generally - theoretical and private, - a practical scale. In economic theory until the 1950s there was no specific procedure for evaluating the quality of expenditure. He dominated "the traditional approach to the definition of" optimal "cost of quality". $100 \%$ compliance with the specification of the product was considered unattainable, so the quality of the price laid down in the purchase after the term. Believed that consumer spending on goods operation inversely proportional to the quality of the goods. They are reduced to the extent of quality goods, tending to zero. The notion of "optimal level of quality." It corresponded to the minimum quality for the cost of the supplier and the consumer. Total costs are defined as the sum of producer and consumer costs.

The second thing to keep in mind the prospect of analyzing the quality of the private self. Private initiative is due to the overall political and economic situation. Socialism could be built in one country, to ensure the competitiveness of socialism was at this historic time impossible. Capitalism is still strong. The same situation and waiting for private producers. Quality product it will release. It can work steadily in an environment that is not ripe for such practices.

Quality product enough to be able to produce. It must be demanded by mass customer, and this situation - is the socio-economic policy. Quality products want to have everything and always. Only it is an abstract desire. It exists as a dream, a fairy tale. Only as regards the status of abstract gaining real possibilities of concreteness propitious conditions for the priority of "good taste", and the buyer will be looking for a quality product, and not to look with envy to cart wealthy, but a clear minority. For producers with the buyer also has its own Higgs field. Of course, in our market there is a certain niche, it enjoys the most respectable part of the middle class. Niche insignificant due skinny social class and instability in a volatile economy. However, this sector has, and under his requests producers of quality products, for example, at 1,500 rubles per kilogram of sausage, shoes for 5000 and more costumes from 15,000 , also exist. But what does this have to do with the market an exclusive characteristic of our economy as a whole? Is, is thus an exception to the rule that only their support. The problem of quality goods manufacturer status - on a national scale and potential of the individual, relatively well-off strata applies to it as the fate of the passengers fleeing in a boat after a storm that made their big ship. But what does this have to do with the market an exclusive characteristic of our economy as a whole? Is, is thus an exception to the rule that only their support. The problem of quality goods manufacturer status - on a national scale and potential of the individual, relatively well-off strata applies to it as the fate of the passengers fleeing in a boat after a storm that made their big ship. But what does this have to do with the market an exclusive 


\begin{tabular}{|c|c|c|c|c|c|c|}
\hline \multirow{4}{*}{ Impact Factor: } & ISRA (India) & $=3.117$ & SIS (USA) & $=0.912$ & ICV (Poland) & $=6.630$ \\
\hline & ISI (Dubai, UAE & $=0.829$ & РИНЦ (Russia & $=0.156$ & PIF (India) & $=1.940$ \\
\hline & GIF (Australia) & $=0.564$ & ESJI (KZ) & $=8.716$ & IBI (India) & $=4.260$ \\
\hline & JIF & $=1.500$ & SJIF (Morocce & $=5.667$ & OAJI (USA) & $=0.350$ \\
\hline
\end{tabular}

characteristic of our economy as a whole? Is, is thus an exception to the rule that only their support. The problem of quality goods manufacturer status - on a national scale and potential of the individual, relatively well-off strata applies to it as the fate of the passengers fleeing in a boat after a storm that made their big ship.

BS Aleshin leads diagram of quality costs developed in TQM [4-5].

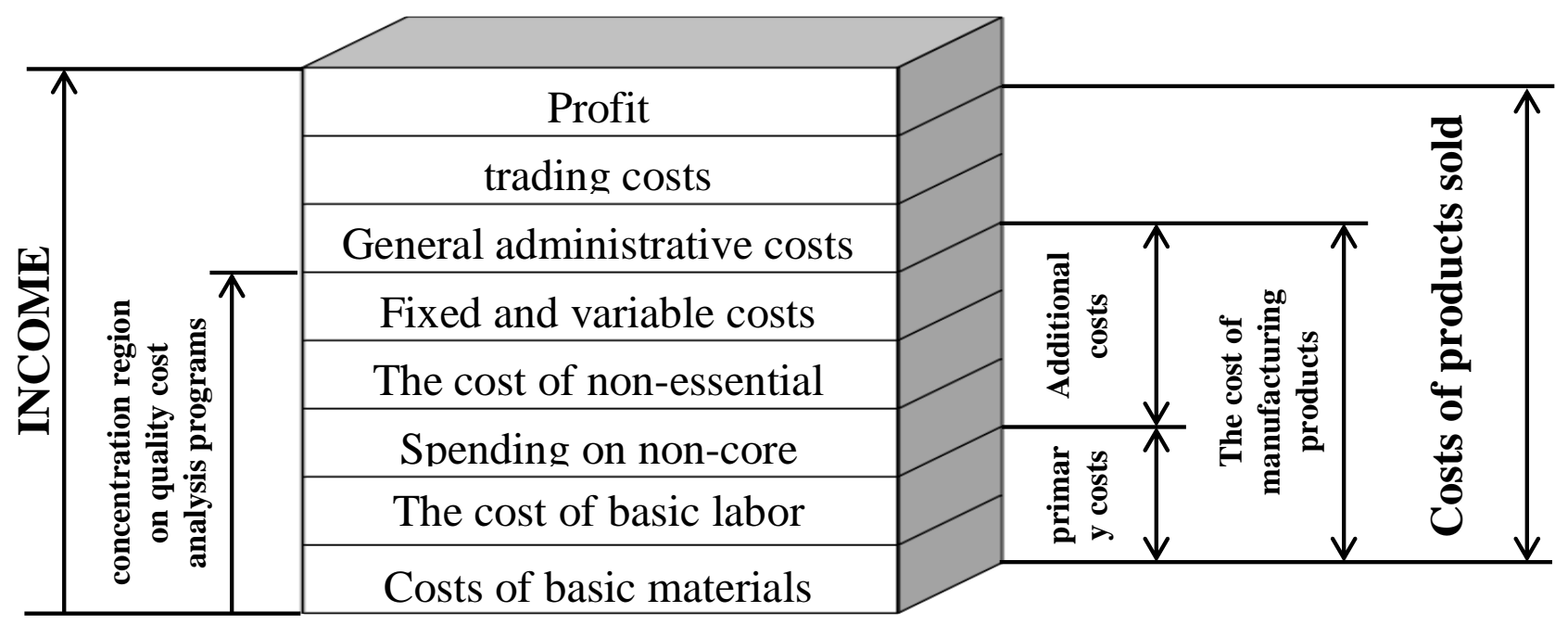

Fig. 1. Structure of income and expenses

Represented by the scheme should be read in two versions - the Euro-americano-Japanese and Russian. They market more than three hundred years. During this time, there was a balance of market forces, and manufacturers have adapted to it. Possible correlation of factors and not perfect, but it reflects an objective position in the market, the manufacturer, seller and buyer. About our market we have said, not all, but most importantly identified. We have the power of the market by intermediaries and speculators, often appear in the same person. It is connected with them, corrupt officials. Therefore, the proportions shown in the right-hand side of the diagram, in our market look different. Especially with regard to the costs of products sold. This part - Klondike for all feeding in the market, and a headache for these workers. Simply because of its advantages no one has refused.

Cash flow for the light industry enterprises located in the regions of the Southern Federal District and the North Caucasian Federal District, is a collection of cash receipts and payments, forming for manufacturers of sustainable technical and economic indicators and they are the guarantor of bankruptcy. Therefore, its management is an integral part of economic policy for the production of marketable and competitive products to consumers in those regions where there is an acute shortage of shoes for children. The authors consider the cash management system as the primary means to protect enterprises from the economic crisis. Cash flows of enterprises of light industry SFD and North Caucasus Federal District in all its manifestations, as well as the aggregate of its cash flow, definitely are one of the most important independent objects of financial management, which requires in-depth theoretical foundations and expansion of practical recommendations. The important role of effective management of cash flows of the enterprise determined by the following key activities: [1]

- implementation of business, so that the cash flows of enterprises of light industry and the regions of the Southern Federal District North Caucasus Federal District will be effective for the formation of a stable job, because It will be the most important feature of the financial health of these companies, a prerequisite for achieving high end results of their economic activity as a whole;

- ensuring the financial equilibrium of the enterprises of light industry SFD and North Caucasus Federal District through effective cash flow management in their strategic development. The result of this process depends on how different types of cash flows are synchronized with each other in terms of volume and time. This affects a significant acceleration of the implementation of strategic business development goals;

- the formation of a rational cash flow enhances the effectiveness of the operational processes of the enterprise. Any failure to make payments has a negative impact on the formation of inventories of raw materials and essential materials, the level of labor productivity, sales of finished products, etc. At the same time, when the cash flows of companies rationally organized, they can ensure the growth of volume of production and sales of their products; 


\begin{tabular}{|c|c|c|c|c|c|c|}
\hline \multirow{4}{*}{ Impact Factor: } & ISRA (India) & $=3.117$ & SIS (USA) & $=0.912$ & ICV (Poland) & $=6.630$ \\
\hline & ISI (Dubai, UAI & $=0.829$ & РИНЦ (Russia & $=0.156$ & PIF (India) & $=1.940$ \\
\hline & GIF (Australia) & $=0.564$ & ESJI (KZ) & $=8.716$ & IBI (India) & $=4.260$ \\
\hline & JIF & $=1.500$ & SJIF (Morocco & $=5.667$ & OAJI (USA) & $=0.350$ \\
\hline
\end{tabular}

- Efficient management of cash flow will reduce the need for enterprises in borrowed capital, this aspect of the management of financial flows relevant to businesses that are in the early stages of its life cycle, with limited access to external sources of financing;

- management of cash flow - an important financial lever to ensure the accelerated capital turnover of enterprises of light industry SFD and North Caucasus Federal District regions, aided by the shortening of production and financial cycles. He reached in the process of effective management of cash flows, as well as reducing the need for capital, serving business activities of these companies;

- Efficient management of cash flow prevents the risk of insolvency of companies. Synchronization receipts and cash payments, which is achieved in the management of cash flows enterprises of light industry SFD and North Caucasus Federal District, eliminates the factor of occurrence of the insolvency;

- rational management of cash flow will allow enterprises of light industry for more profit to be used for the social protection of workers and the workers of these enterprises and their families.

Thus, the effective cash flow management enterprises of light industry SFD and North Caucasus Federal District regions contributes to the creation of additional investment resources for the implementation of financial investments, which are a source of profit. The above aspects confirm the need for cash flow businesses into an independent financial control object with the appropriate structural and staffing of control. the company's cash flow management is an important part of the overall management of its financial system. This process allows you to solve various problems of the financial management of the enterprise, and it is subordinated to the main goal.

The process of managing the cash flow of enterprises of light industry SFD and North Caucasus Federal District is based on certain principles regions, which are summarized in Table 1. Their implementation is the basis for successful activity as a working light industry, and for the newly created to address the acute shortage of products for children . Effective management of cash flow based on providing financial equilibrium by balancing these enterprises Incoming volumes and spending money, and using these principles by means of the control given in Table 1.

Analysis of cash and cash flow management comprises the following steps [2]: cycle);

- Calculation of cash handling time (the financial

- cash flow analysis;

- its forecasting;

- definition of an optimal level of cash;

- Preparation of cash budgets.

The main tasks of funds analysis is operational and day to day control over the safety of cash and securities in the cash register of enterprises; Control over the targeted use of funds; monitoring the correct and timely payments to the budget, suppliers and staff.

Table 1 - The principles of cash management businesses

\begin{tabular}{|c|c|}
\hline Принципы управления финансовыми потоками & Характеристика принципов \\
\hline Обеспечение эффективности & $\begin{array}{lcr}\text { Oсновывается } & \text { на } & \text { обеспечении } \\
\text { эффективного } & \text { управления } & \text { денежными } \\
\text { потоками использования } & \text { посредством } \\
\text { осушествления } & \text { финансовьг } & \text { инвестиций } \\
\text { предприятий } & & \end{array}$ \\
\hline Обеспечение ликвидности & $\begin{array}{lrrr}\text { Обеспечивается } & \text { с } & \text { помощью } \\
\text { соответствующей } & & \text { синхронизации } \\
\text { положительного } & \text { и } & \text { отрицательного } \\
\text { денежньг потоков } & \text { в } & \text { разрезе каждого } \\
\text { временного интервала } & \text { рассматриваемого } \\
\text { периода } & & \end{array}$ \\
\hline Информативная достоверность & $\begin{array}{l}\text { Заключается в отсутствии финансовой } \\
\text { отчётности, которая базируется на единьх } \\
\text { методических принципах бухгалтерского } \\
\text { учёта. Поэтому создание необходимой } \\
\text { информационной базы не представляется } \\
\text { возможным }\end{array}$ \\
\hline Обеспечение сбалансированности & 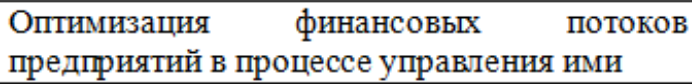 \\
\hline
\end{tabular}




\begin{tabular}{|c|c|c|c|c|c|c|}
\hline \multirow{4}{*}{ Impact Factor: } & ISRA (India) & $=3.117$ & SIS (USA) & $=0.912$ & ICV (Poland) & $=6.630$ \\
\hline & ISI (Dubai, UAE & $=0.829$ & РИНЦ (Russia & $=0.156$ & PIF (India) & $=1.940$ \\
\hline & GIF (Australia) & $=0.564$ & ESJI (KZ) & $=8.716$ & IBI (India) & $=4.260$ \\
\hline & JIF & $=1.500$ & SJIF (Morocce & $=5.667$ & OAJI (USA) & $=0.350$ \\
\hline
\end{tabular}

\section{Conclusion.}

Also, the main tasks of the analysis relates cash monitoring compliance calculations forms established in the contracts with customers and suppliers; timely reconciliation of calculations with debtors and creditors in order to avoid overdue debts;

- analysis of the state of absolute liquidity of enterprises;

- compliance with the terms of payment of accounts payable;

- to contribute to competent management of cash flow businesses.

To conduct cash flow analysis using two methods: direct and indirect. The direct method is the arrival terms (revenues from sales of products, works and services, advances, etc.) And flow (payment of suppliers' invoices, the return of short-term loans and credits, etc..) In cash. The indirect method consists of identifying and accounting operations related to cash flow, and consistent adjustment of net profit, ie, profit is the starting element. The direct method of calculation is based on the reflection of the results of operations (rotations) on the accounts of cash flows for the period. The operations can be divided into three types of activities [3]:

- the current (operational) activity - getting sales revenue, advances, payment of suppliers' invoices, obtaining short-term loans, payment of wages, calculations with the budget, paid or received interest on loans;
- financial activities - to obtain long-term loans, long-term and short-term investments, repayment of loans and payment of dividends already received.

- investment activity - the process of the movement of funds related to the implementation, the acquisition of intangible assets and fixed assets.

Calculation of cash flows direct method makes it possible to assess the solvency of enterprises of light industry SFD and North Caucasus Federal District, as well as in operational control of the movement of funds. The indirect method is preferred from an analytical point of view, since it allows you to determine the relationship of profits to changes in the value of financial flows of these enterprises. Under this method, cash flows are calculated on the net income with the necessary adjustments in its articles do not reflect the actual movement of money on the accounts.

The authors examined the effects of the financial aspects of enterprises of light industry SFD and North Caucasus Federal District in the product life cycle. Considered cash flow management principlesandand shows the impact of cash flow of these companies in their technical and economic parameters. The implementation of these aspects creates a basis for the prevention of enterprises of light industry from bankruptcy.

\section{References:}

1. Prohorov, V. T., et al. (2017). Concept import light industry: background, objectives, innovations. monograph / under the total. Ed. Dr. tehn. Sciences, prof. VT Prokhorov (Eds.). Institute of Entrepreneurship and Service sector (branch) of the Don State Technical universiteta. (p.334). Novocherkassk: Leake.

2. Prohorov, V. T., et al. (2014). Quality Revolution: quality through advertising or through real quality: monograph under the total. Ed. prof. VT Prokhorov (Eds.). ISOiP (branch) DSTU. (p.384). Novocherkassk: YURGPU (NPI).

3. Gretskaya, L. G., et al. (2012). The effect of cash flow on the performance of the cluster formed on the base of the shoe enterprises SFD and North Caucasus Federal District / under the total. Ed. prof. VT Prokhorov (Eds.). (p.354). Mines: VPO "SRSUES".

4. Vdovin, L. P., Prokhorov, V. T., Aspen, T. M., Myaleshka, E. N., \& Osatskaya, N. V. (2014). The means of achieving sustainable technical and economic performance of the shoe enterprises SFD and North Caucasus Federal District. Memory VA Fukin is dedicated: Sat. scientific. articles and vospominaniy. Part 3. (pp.32-41). Moscow: MSUDT.

5. Mishin, Y. D., et al. (2008). Quality Management competitive and sought-after materials and products. Monograph / under the general editorship of prof. VT Prohorova (Eds.). (p.654). Mines: Publishing House of the GOU VPO "SRSUES".

6. Prohorov, V. T., et al. (2012). Managing the production of competitive and marketable products. under the total. Ed. prof. VT Prokhorov (Eds.). VPO "SRSUES". (p.280). Novocherkassk: SRSTU (NPI).

7. Golovko, A. V., et al. (2019). On the possibilities of regulatory documents developed by the system Quality Management (QMS) for the digital production of defect-free import-substituting products. monograph / under the total. Ed. Dr. those. Sciences, prof. VT Prokhorov (Eds.). 


\begin{tabular}{|c|c|c|c|c|c|c|}
\hline \multirow{4}{*}{ Impact Factor: } & ISRA (India) & $=3.117$ & SIS (USA) & $=0.912$ & ICV (Poland) & $=6.630$ \\
\hline & ISI (Dubai, UAE & $=0.829$ & РИНЦ (Russia) & $=0.156$ & PIF (India) & $=1.940$ \\
\hline & GIF (Australia) & $=0.564$ & ESJI (KZ) & $=8.716$ & IBI (India) & $=4.260$ \\
\hline & JIF & $=1.500$ & SJIF (Morocco) & $=5.667$ & OAJI (USA) & $=0.350$ \\
\hline
\end{tabular}

Institute for consumers services and enterprise (branch), Don State Technical University. (p.227). Novocherkassk: Leake.

8. (2018). Upravlenie quality products through the motivation of behavior of light industry enterprise team leader: monograph / under total. Ed. Dr. tehn. Sciences, prof. VT Prokhorov (Eds.). Institute for consumers services and enterprise (branch), Don State Technical University. (p.336). Novocherkassk: Leake.

9. Prohorov, V. T., et al. (2013). Sinergetika formation of a competitive range of the domestic footwear: monograph / under the total. Ed. prof. VT Prokhorov (Eds.). ISOiP (branch) DSTU. (p.194). Mines: ISOiP (branch) of Dagestan State Technical University.

10. Surovceva, O. A., et al. (2018). No open 10-real quality products rather than advertising through behavioral motivation of the enterprise team leader lYe with gravesoftwood industry: Monograph / under obsch.red. Dr. tehn. Sciences, prof. VT Prokhorov (Eds.). Institute of Entrepreneurship and Service sector (branch) of the Don State Technical university. (p.384). Novocherkassk: YURGPU (NPI).

11. Prohorov, V. T., et al. (2018). The competitiveness of enterprises and the competitiveness of products - the key to a successful import of goods demanded by consumers The region is the Southern Federal District and the North Caucasian Federal District. Collective monograph / under the total. Ed. Dr. tehn. Sciences, prof. VT Prokhorov (Eds.). service sector and entrepreneurship Institute (branch) of the Don State Technical universiteta. (p.337). Novocherkassk: Leake.

12. Prokhorov, V. T., et al. (2015). The range and assortment policy. monograph / under the total. Ed. Dr. tehn. Sciences, prof. VT Prokhorov (Eds.). Institute of Entrepreneurship and Service sector (Phil.) Feder. state. budgets. obrazovat. postsecondary institution. prof. Education "Don State. tehn. Univ "in Mining Height. region. (ISOiP (branch) DSTU). (p.503). Novocherkassk: YURGPU (NPI). 